\title{
Environmental Civil Liability under comparison: Some notes in soft law
}

Dr. Santiago Areal Ludeña

Profesor Doctor Chair Professor of International Private Law at University Carlos III de Madrid; Director of several postgraduate studies.

Jorge Alberto Fierro Abella

PhD Candidate (Graduate School, ILE Hamburg), sponsored by the Deutsche Forschungsgemeinschaft (DFG); LL.M in Law and Economics (Hamburg); LL.M in Private Law (Madrid); LL.M in International Trading (Madrid).

\section{RESUMEN}

La responsabilidad civil medioambiental sirve como complemento de políticas públicas de regulación. Desastres naturales de devastadora magnitud, paralelo al incremento desmesurado de la población mundial, han capturado la atención de políticos y legisladores a escala global. Preocupantes informes de naturaleza tanto oficial como independiente, concluyen en la imperiosa necesidad de establecer un término para el cambio. Los vacíos dejados por débiles instrumentos internacionales sólo pueden ser subsanados por el estudio comparativo de aquellas normativas que han probado cierto éxito doméstico. Consecuentemente, soluciones europeas y norteamericanas son referenciadas en la actualidad por países en desarrollo. En el presente estudio centraremos nuestra atención en tales desarrollos jurídicos, especialmente en aquellos brindados por el denominado soft law.

Después de abordar las especiales características del daño medioambiental, en relación con el daño tradicional, haremos lo propio con los demás elementos configuratorios de la responsabilidad civil. Posteriormente, estudiaremos los elementos característicos de los modelos europeo y norteamericano. Intentaremos dar respuesta a la marcada influencia que históricamente ha ejercido el sistema norteamericano a nivel mundial, así como si ello resulta retrospectivamente justificable. No pasaremos por alto las directivas europeas que desde 1986 hasta 2004 han incorporado importantes avances respecto de su par Transatlántico. Este será el primero de subsiguientes esfuerzos por incluir un análisis interdisciplinario que involucre tópico tales como la prevención y la autorregulación del daño medioambiental.

\section{ABSTRACT}

Environmental liability is the private complement to public regulation. Devastating environmental disasters along with an increasing demanding population for natural resources have captured the attention of politicians and law makers across the globe. Alarming official and independent research have concluded that a deadline for change must be set. The gaps left by weak international instruments can only be filled by a comparative analysis of those national legal embodies that have proven certain level of success. Admittedly leading legislations such as in the US and Europe play nowadays the role of guides for developing countries. In the following paper we focus on how the solutions provided in soft law material of the prior could be implemented in the latter. 
After addressing the special characteristics of environmental tort as compared to traditional tort, we examine the elements of environmental civil liability; explore the reasons of why liability standard changed in environmental tort, and outline the potential defenses and remedies. In a subsequent section, we introduce the main legal principles and doctrines that provide the basis for the environmental civil liability regime in the U.S, and compare the two methods primarily used by the U.S. We then examine the environmental civil liability structure in the EU. After analyzing the reasons why the EU has had to intervene into environmental civil liability field, we chronologically examines every directive with regard to civil liability that EU has proposed from 1986 to 2004, and end with a brief conclusion of the features of EU's environmental civil liability regime. This is the first of further attempts that will involve an interdisciplinary analysis to the problem of incentives and deterrence of environmental damage.

\section{PALABRAS CLAVE}

Responsabilidad civil, ambiental, derecho ambiental, políticas públicas ambientales, Soft law.

\section{KEYWORDS}

Environmental civil liability, soft law environmental law.

\section{INTRODUCTION}

"Gulf of Mexico oil leak 'worst US environment disaster', said a senior officer", reported the BBC to the World ${ }^{1}$. According to unconsolidated data, more than 76 million barrels of heavy oil have devastated over 46.000 square miles of enriched ecosystems. Billions of dollars have already been spent by the BP and many more wait for the results of thousands of judicial claims. Nonetheless, many will only perceived its collateral effects decades later, a situation that comprises many jurisprudential challenges.

On November $13^{\text {th }}, 2005$, a large chemical plant exploded in Jilin, an industrial city in China, resulting in a severe pollution of a river that provides drinking water to Harbin, one of China's largest cities. The explosion sent an unknown quantity of benzene into Songhua River; benzene is a highly toxic and flammable industrial solvent and a known carcinogen. Scientists noted that benzene levels in the river were more than 100 times the safe level. As a result of this incident, water service to the 4 million residents of Harbin was suspended for at least four days $^{2}$. Fortunately, nobody died as a result of the pollution to the Songhua River; however, this is not always the case. In the past 50 years, millions of innocent people have died from environmental pollution, and the number of people who are suffering from diseases caused by environmental incidents is even greater.

The Bhopal Accident is probably the greatest industrial disaster in history. Between 1977 and 1984, UCIL, an Indian company located in a crowded working class neighborhood in Bhopal, was licensed by the Madhya Pradesh Government to manufacture phosgene, monomethylamine (MMA), methylisocyanate (MIC) and the pesticide carbaryl, all of which were highly contaminated. On the night of December 2, 1984, due to the corrosion of the stainless steel tanks that contained MIC and other reaction products, these highly toxic substances escaped from the factory and spread to the surrounding areas. What was worse was that the emergency sirens had been switched off, and therefore, people living around the factory could not be warned of this environmental danger. The effect of these hazardous substances was immediate and devastating. Many innocent people died in their sleep; others struggled to get out of their homes, blinded and choking, only to die on the streets.

\footnotetext{
${ }^{1}$ BBC Online, 30.05.10 (available at http://www.bbc.co.uk/news/10194335) (consulted on 10.08.10).

${ }^{2}$ China:Severe Water Pollution in Harbin's River, http://www.voanews.com/burmese/archive/2005-11/2005-11-23-voa6.cfm?CFID $=296560725 \&$ CFTOKEN $=45652787$
} 
Hundreds of people died later after arriving at hospitals. The estimated number of people who died from this environmental disaster was at least 3,000 , while the number of injured people was around $500,000^{3}$.

The Bhopal Accident is definitely not the only tragedy that was caused by environmental pollution. Ever since the 1930s, millions of people have been killed in various environmental incidents, from air pollution to water pollution, and to land pollution. Especially in recent 30 years, there is a clear sign that indicates environmental pollution tends to be transboundary, not only within one single nation, but also many countries that are geographically close to each other. Moreover, the harm of pollution has the tendency of being more severe and the latency much longer. Eventually, these characteristics attracted popular attention. People began to take many efforts to prevent more pollution and also minimize the influence of pollution that had already taken place, employing both technological and legal means. The legal approach to pollution control focused on the liabilities that resulted from environmental incidents. The questions that resulted contemplated when someone should be liable for his action if that action causes damages to the environment. Other questions included: Could traditional tort theory still be applied to modern environmental tort actions? Under what conditions can a polluter be exempted from his liabilities?

The United States and European Union are considered to be pioneers in the law making areas regarding environmental pollution. Even though we cannot say that their environmental liability systems are perfect, still they largely guide the world regarding environmental law. The search for international domestically enforceable instruments must take into account the steps taken by the so- called first-world countries ${ }^{4}$. The existing laws with regard to environmental civil liability in developing nations ${ }^{5}$ fail to keep the pace of the development of modern environmental torts.

This paper focuses on the special features of modern environmental torts, and discusses how the U.S and the EU react to these features in their legal systems. Due to the large amount of legal instruments directly and subsidiary applicable, a first aim refers to soft law. By carefully reviewing their environmental civil liability structures, we hope this article can help lawmakers of developing countries learn from other countries' successes and failures in the realm of effective environmental civil liability. Special attention will be put on China. Once again, a central goal of International regulation shall not be discarded. It must be warned that this is the first of further attempts that will involve not only other embodies of the law but also interdisciplinary approaches of it.

This paper first reviews the term "environmental civil liability", and then, it addresses the special characteristics of environmental tort as compared to traditional tort, examines the elements of environmental civil liability, explores the reasons of why liability standard changed in environmental tort, and outlines the potential defenses and remedies. In the next section, it introduces the main legal principles and doctrines that provide the basis for the environmental civil liability regime in the U.S, and compares the two methods primarily used by the U.S. It then examines the environmental civil liability structure in the EU. After analyzing the reasons why the EU has had to intervene into environmental civil liability field, it chronologically examines every directive with regard to civil liability that EU has proposed from 1986 to 2004, and ends with a brief conclusion of the features of EU's environmental civil liability regime.

\footnotetext{
${ }^{3}$ http://www.corrosion-doctors.org/Pollution/bhopal.htm.

${ }^{4}$ A strong but undoubtedly refutable assumption suggests that economic development goes hand-to-hand to appropriate regulation on the usage of natural resources. This seems to hold at least on own jurisdictions. The issue here is not whether countries such the US or Germany misuse foreign natural resources (they might at least in some subsidized industries, or whenever raw materials are underpriced); but as how environmental statutes achieved the pursued goal of punishment and deterrence.

${ }^{5}$ Once again, the concept of "developing country" is not related to economic growth. As a matter of example, China has unsuccessfully tried to harmonized GDP with environmental sustainability.
} 


\section{DEFINITION, SPECIAL FEATURES AND ESSENTIAL ELEMENTS OF ENVIRONMENTAL CIVIL LIABILITY}

Environmental civil liability is a main component of the liability regime for environmental damages. Although it shares many theories with traditional tort system, it is not exactly the same one that appears in traditional tort. The special features of environmental tort demand distinctions and improvements from the traditional tort regime. This section provides an overall review of environmental civil liability and discusses its similarities and distinctions with traditional tort.

\subsection{Definition of Environmental Civil Liability}

To explore the definition of environmental civil liability, it is a good choice to start with the term "liability." Generally speaking, liability has two meanings. On one hand, it is defined as "the quality or state of being legally obligated or accountable; legal responsibility to another or to society, enforceable by civil remedy or criminal punishment. ${ }^{\prime \prime}$ At this point, it is also termed legal liability; responsibility; subjection. ${ }^{7}$ Concretely speaking, in this sense, liability is used in two ways. First, it is the synonym of duty, the correlative of right, and the opposite of privilege or liberty. "If a duty rests upon someone, society is commanding performance by him and threatening penalties."

For example, everyone has the liability to follow the statutes and regulations. Second and more often, liability is used as the correlative of power and the opposite of immunity ${ }^{10}$. In this case "society is not yet commanding performance, but it will so command if the possessor of the power does some operative act. If one has a power, the other has a liability."'11 According to this definition, you are liable for assaulting someone else. On the other hand, liability sometimes refers to "a financial pecuniary obligation," ${ }^{, 2}$ and is used in plural form, such as in the phrase "assets and liabilities." ${ }^{\text {"13 }}$ The term liability discussed through this paper is especially referred to the second aspect under the first meaning.

When one is legally obligated for civil damages, he or she is supposed to hold civil liability for the damages. Similarly, when one's conduct causes environmental damage so as to infringe other people's private rights, he or she has to accept environmental civil liability for his or her conduct. In civil law countries, environmental civil liability mainly consists of environmental tort liability, which is regulated under various statutes and regulations, while in common law countries, environmental tort liability refers to a liability that comes about through common-law notions of tort theory, such as trespass, nuisance or negligence. In contrast, civil liability refers specifically to liabilities that are set forth in statutes, created by legislatures. To avoid confusion, environmental civil liability is used as a general concept that is comprised of both tort liability and other liabilities for breach of statutory duty throughout this paper. Together with environmental criminal liability and administrative liability, environmental civil liability constitutes the liability regime for environmental damage.

\subsection{Characteristics of Environmental Tort as Compared to Traditional Tort}

In recent times, air pollution brings out images of urban smog and acid rain that affect the whole public, imposes incalculable risks, and emanates from uncertain sources. However, the action has moved elsewhere to some degree. Insults from smoke, noise and odors to the public have been overshadowed by a chemical revolution that seems to portend quantities of unseen risks in everyday life from the synthetic products that we routinely

\footnotetext{
${ }^{6}$ Black's Law Dictionary (8th ed. 2004), LIABILITY.

${ }^{7}$ Id.

${ }^{8}$ William R. Anson, Principles of the Law of Contract 9 (Arthur L. Corbin ed., 3d Am. ed. 1919).

${ }^{9}$ Id.

${ }^{10} \mathrm{Id}$.

${ }^{11}$ Id.

${ }^{12}$ Black's Law Dictionary, supra note 1.

${ }^{13}$ Id.
} 
encounter. ${ }^{14}$ With these changes, over the last two decades, a new class of torts has emerged that targets personal injuries caused by toxic substances in the environment. These hybrid environmental torts are quite different from the trespass-nuisance precedent that is part of traditional tort theory.

\subsubsection{Indirect Tort Action}

Tort is divided to direct tort and indirect tort. Most traditional torts are direct, which means that the conduct functions directly upon victims, while in environmental tort, the conduct first pollutes the environment, which then causes personal injuries or / and property damages. Thus, in environmental tort, most conduct seems not to have a direct causal link with the harm suffered by victims. The nature of environmental tort is that such tort uses environment as a medium to cause harm to people, either their bodies or properties.

\subsubsection{Difficulty of Determining Defendant}

Identification of defendants who are liable for the environmental damage is harder to figure out than in traditional tort. As in any tort action, to bring an environmental tort suit the plaintiff must prove that the defendant is responsible for the harm at issue. But the source of the environmental contaminant is not always easily identifiable, especially if that substance was released into the environment long ago. Moreover, in some cases there are multiple sources of the environmental pollutant that brings harm to the plaintiff. Even when all potential sources can be identified, it may be difficult or impossible to determine the proportion of each source's responsibility for the total harm that has occurred. ${ }^{15}$

\subsubsection{Difficulty of Pinpointing Plaintiff}

Just like the frequent difficulty to identify the party or parties responsible for causing the environmental harms, it may also be difficult to determine the party or parties who have suffered injury caused by harmful environmental exposure. This characteristic of environmental tort is closely related to the character of the environmental elements. Generally speaking, environmental elements consist of natural elements and social elements. Here it refers to those natural elements such as water, air, rock, living creatures, sunshine and soil. Environmental tort is an indirect tort action that uses environmental elements as its intermediary. Natural elements such as water, air and living creatures are part of the environmental cycle. Meanwhile, those pollutants or contaminants are also in the cycle and are brought everywhere by the natural elements. In other words, environmental pollution is not limited to one area. For instance, a sandstorm in north China can influence South Korea and Japan. Take disease for another example. Many diseases have multiple causes. For most diseases there is a "background rate" at which the population contracts the disease. ${ }^{16}$ Even if exposure to a substance is known to cause a particular type of cancer to those exposed, some of the exposed population would have developed this form of cancer even though they are absent from the exposure. ${ }^{17}$ And these individuals would have figured in the background rate. $^{18}$ Thus, there is no affirmative answer to the question whether the exposure to a substance that could have caused a particular disease in a particular plaintiff did in fact cause the disease in that plaintiff. Therefore, sometimes it is a big problem to determine the plaintiff.

\subsubsection{Unequal Status of Plaintiff and Defendant}

Fairness is the soul of civil law, and therefore, the most obvious character of civil law is that the status of plaintiff and defendant are equal. Traditionally, tort occurs between farmers, craftspeople and small proprietors. Since the status of plaintiff and defendant is equal, it is possible that their identities

\footnotetext{
${ }^{14}$ Huanjingfa Yuanli [Principles of Environmental Law] 157, ( Lv Zhongmei ed., 1st ed., 2007) Fudan Press.

${ }^{15}$ See Kenneth S. Arbraham, Individual Action and Collective Responsibility: The Dilemma of Mass Tort Reform, 73 Va. L. Rev. 845 (1987).

${ }^{16}$ See David Rosenberg, The Causal Connection in Mass Exposure Cases: A “Public Law” Vision of the Tort Syetem, 97 Harv. L. Rev.849 (1984). ${ }^{17}$ Id.

${ }^{18}$ Id.
} 
exchange later, which means a plaintiff could be a defendant in another tort case. By contrast in environmental tort, defendants are usually enterprises that are equipped with advanced techniques and updated information and have a special economic status in the country while the plaintiffs or victims are ordinary people that have little knowledge about, and evidence of, the sorts of chemicals that plants leak or emit. They have problems to establish the legal causation between the harm they suffer and the breaching of duty by an enterprise or enterprises. Moreover, the litigants are uncertain about the chemicals to which they have been exposed and may discover the injury only after the statute of limitations has run.

\subsubsection{Problems of Identifying the Damage}

Throughout the centuries of tort law development, the identification of an injury has hardly ever been a problem. It is most of the time the unexpected intrusion on other people's land or violation of a right to bodily integrity. ${ }^{19}$ In contrast, in environmental tort, toxics such as impure water, hazardous chemicals, and defective synthetics often breed disease rather than cause immediate injury. These diseases do not occur instantaneously. And because diseases are frequently a product of the background risks of living, technical information is essential to establish causal link between the tortious conduct and the harm. Thus, identification of the injury, ordinarily a routine issue in traditional tort, is a costly task that relies on types of evidence and probability judgments which can be regarded as ill-suited to traditional resolution through the adversary process. ${ }^{20}$

\subsubsection{Long Latency of Harm}

As to most traditional torts, once the tort action occurs, the harm comes out with the action, and such harm also disappears once the action stops.
However, in environmental tort, harms usually last for a considerably long time. For instance, on April 26,1986 , a nuclear leak and explosion took place in Russian Chernobyl nuclear power plant. ${ }^{21}$ Thirtyone people died on the day of the leak. ${ }^{22}$ Tens of thousands of people died or suffered serious illness as a result of the radioactive fallout. ${ }^{23}$ To this day, radiation causes serious birth defects. ${ }^{24}$ Thus, the environmental damage lasts for at least 21 years, with no way of knowing how much longer these terrible effects will continue. Moreover, many damages take place slowly and invisibly, only to become detectable many years after the event that caused the damage. Just like certain diseases, there is a long latency period between the time of exposure to a pollutant and the time the diseases resulting from that exposure manifest themselves. Another possibility is that some environmental damages may begin to occur immediately or soon after the release of a substance, but at that time they are not detected or detectable. It is not until many years later do people suddenly realize the existence of those harms. For example, hazardous waste can seep into groundwater and begin to migrate offsite shortly after it is deposited, but the resulting contamination of drinking water may not be discovered until much later. ${ }^{25}$

In fact, other characteristics of environmental tort are each partly related to the uncertainties that result from the long latency of many environmental damages. Traditionally, it is the plaintiff who bears the burden of proof in a tort claim. Proof of the evidence of negligence (or in some cases the requisites of strict liability), causal connection, and both past and future damages is therefore required. Yet because of the long latency of most of the harms at issue in environmental tort cases, evidence of exactly what the defendant did may be uncertain; scientific and medical proof of a causal link between the defendant's conduct and the plaintiff's injury may make it difficult to adduce. Further, the long

\footnotetext{
${ }^{19}$ See Robert L. Rabin, Environmental Liability and The Tort System, 24 Hous. L. Rev. 27 (1987).

${ }^{20}$ Id.

${ }^{21}$ The Accident in Chernobyl, http://baike.baidu.com/view/412925.htm.

${ }^{22}$ Id.

${ }^{23}$ Id.

${ }^{24}$ Id.

${ }^{25}$ Kenneth S. Abraham, The Relation Between Civil Liability and Environmental Regulation: An Analytical Overview, 41 Washburn L.J. 379.
} 
latency of harm also brings difficulties in identifying defendants and pinpointing victims.

\subsubsection{Severity of the Harm}

Environmental torts are usually more severe than those of traditional torts not only because of their long latency and post-generational consequences, but also because of the difficulty to limit them within a certain boundary. The crux of the matter is the distinction between the accidents. The harm suffered in an airplane crash is extensive but it is also bounded. Most of the victims die, but apart from derivative loss, there are virtually no consequences beyond the very spot of the crash. On the contrary, in environmental torts, the damages are potentially unbounded. Take Chernobyl nuclear power plant for example again. After the explosion, the radiation expanded with wind to the western area of former Soviet Union, Eastern Europe, and even reached the Scandinavian Peninsula, resulting in the deaths of more than 4,000 people and various sicknesses. ${ }^{26}$ In a word, the extent of an environmental disaster is just unpredictable and the array of disorders is far more wide-ranging.

\subsubsection{Reasonableness of the Tortious Action}

Actions, such as those that causing physical injury or property damage to other people, are most of the time endangering social order and security. However, it is hard to conclude that conducts constituting environmental torts are the same as those in traditional torts. Basically they are legal actions, or to say, at least not prohibited by law. For instance, there is no law forbidding pouring waste water into rivers; one is not liable until such pouring pollutes the waters and inflicts personal damages. Unlike beating someone on the face that directly violates the right of that person's body integrity, pouring water itself does not violate any law. Therefore, under most circumstances, the actions that cause environmental torts are not illegal.

\subsubsection{Inevitability of the Tortious Action}

Compared to people in traditional torts who may be able to avoid the damages once they exercise due care, operators in environmental torts may still be unable to avoid the damages even if they have already exercised duty of care with the knowledge of modern techniques. The reason is that environmental damages are the "by-product" of the manufacture of industrialization and civilization. It is the price that human beings have to pay for the use and change of nature. If environmental torts were completely eliminated, people would have to step back to the primitive society.

\subsection{Elements of Environmental Liability under Tort}

What elements constitute environmental torts is the threshold question to the environmental civil liability. ${ }^{27}$ It is also one of the fundamental questions to the theory of environmental tort. ${ }^{28}$ Since environmental tort is a special kind of tort, the understanding of the components of environmental tort is closely related to the elements of traditional tort.

The differences between the requirements of the various torts relate to just a few points. ${ }^{29}$ Since the basic complaint in a tort case is "You hurt me," the three crucial focal points are, first, what the alleged tortfeasor did; second, what the claimant suffered in consequence; and third, how the suffering resulted from the conduct. ${ }^{30} \mathrm{It}$ is very important to keep these matters distinct. How the defendant behaved is the cause and what the claimant suffered is the effect. Both of these are provable facts. How the conduct resulted in the harm is not quite as provable as the first two. It is the relationship between those two facts, which is called "causation". In conclusion, the three focal elements are conduct, harm, and causation.

\footnotetext{
${ }^{26}$ http://news.sohu.com/s2006/06qenbl/

${ }^{27}$ Cao Mingde, Huanjing Qinquanfa [Environmental Tort Law] 158, the Legal Press (2000).

${ }^{28}$ Id.

${ }^{29}$ Tony Weir, Tort Law 12, Oxford University Press, (2002).

${ }^{30}$ Id.
} 


\subsubsection{Conduct}

For centuries, fault has been considered the basis of tortious conduct. ${ }^{31}$ By 1850 's, it became increasingly accepted that "sound policy lets losses lie where they fall, except where a special reason can be shown for interference. ${ }^{.32}$ Apart from a few exceptional situations such special reason was the tortfeasor's fault. ${ }^{33} \mathrm{~A}$ person at fault was guilty not only of a legal wrong but also of an ethical wrong. As Professor Fleming once said: "the triumph of fault liability was well-nigh complete and marked a singular judicial triumph in remolding ancient precedents in the image of a radically different ear. ${ }^{\text {"34 }}$

However, when it comes to environmental tort, fault tends to be neither one of the characters of tortious conduct and nor a requirement of tortious liability. Rather, the principal focus rests with the relationship between conduct and harm. In other words, one can be held liable not only when one intends to cause an invasion of an environmental interest legally protected, or when one negligently creates an unreasonable risk of invasion of such an interest, but also when one carries on a conduct at the risk that the actor shall be subject to liability for the environmental harm caused thereby. This is true even if no such harm is intended and the harm cannot be prevented by any precautions or care which it is practicable to require. Once the causal link between the conduct and the environmental harm has been established, whether the actor is subjectively wrong or his conduct is illegal are beyond concern. The reason for such tendency is that victims of environmental damages generally lack sufficient resources to challenge polluters and they need law to protect them. Furthermore, most of the environmental damages are large-scale disasters, holding polluters accountable and deterring them from harming the environment.

\subsubsection{Harm}

There are various kinds of harms in environmental torts, such as damage to property, physical harm, psychiatric injury and illness, and also infringement of the rights to environment. ${ }^{35}$

Damage to property is calculable economic loss. It can be further divided into two forms. ${ }^{36}$ The first one is directly caused by the environmental tortious conduct. For example, a fish pond is polluted by the waste water discharged by a chemical factory. A large quantity of fish die and Mark, the owner of the pond suffers the loss of much money. The other form is the economic loss brought by bodily harm or psychiatric injury. It is indirectly caused by the environmental tortious conduct. For instance, the same Mark gets sick after eating the fish from the polluted pond. Money he has to pay for the treatment of his illness and the loss of salary when he is in the hospital also constitutes property damage.

Physical harm usually appears in the form of death or loss of bodily functions. ${ }^{37}$ For example, from 1953-1968, people at Minamata Bay in Kumamoto Prefecture, Japan, consumed fish, shellfish and other aquatic organisms living in the gulf, which had been polluted by sewage containing mercury and methylmercury. Nearly 10,000 people suffered from a variety of central nerve diseases. Among the 283 patients who were poisoned by methylmercury, more than 60 died $^{38}$.

Another example of environmental harm is injury to psyche, which manifests itself in victims' mental suffering and flesh pain. Neurasthenia resulting from noise pollution is one kind of injury. Since such injury is hard to see, feel and figure out by other people except for the victim, it is also called invisible

\footnotetext{
${ }^{31}$ See Simon Deakin, Angus Johnston, and Basil Markesinis, Markesinis and Deakin's Tort Law, Clarendon Press (5th ed., 2003).

${ }^{32}$ Id, at 42.

${ }^{33}$ Id, at 42.

${ }^{34}$ Fleming, J.G., The Role of Negligence in Modern Tort Law, 53 Virginia LR 815 (1967).

${ }^{35}$ Cao Mingde, Huanjing Qinquanfa [Environmental Tort Law] 158, the Legal Press (2000).

${ }^{36}$ Id.

${ }^{37}$ Id.

${ }^{38}$ Eight World Well-known Environmental Hazards Incidents, http://bbs.hitfm.cn/lofiversion/index.php/t43381.html.
} 
harm. ${ }^{39}$ In common law countries, damages cannot be recovered for mere grief or emotional distress from an injury or death of someone else, even if that someone is a loved one. ${ }^{40}$ However, mere grief and a serious, prolonged psychiatric condition are different in principle. The latter may be identified with the help of expert medical testimony. ${ }^{41}$ Medical science now recognizes a condition known as "posttraumatic stress disorder", which may occur in reaction to the violent or unexpected death of a close relative or friend. ${ }^{42}$ The starting point is the case Alcock v. Chief Constable of South Yorkshire, in which plaintiffs were held to be compensated for their psychiatric injury. ${ }^{43}$ In Japan, when deciding the case of hazardous pollution in Yokkaichi, judges also took psychiatric injuries into consideration. ${ }^{44}$ In China, although there are no provisions for psychiatric damages in civil law, compensation for psychiatric injury from environmental pollution does exist in practice.

Loss of the right to environment is also a type of environmental harm. Right to environment is defined as the right of the public to have a healthy, secure, quiet, comfortable and graceful environment. ${ }^{45}$ Infringement of rights to environment means interference with the public's enjoyment of the environment. For instance, the construction of a building that is beyond the maximum height set by law interferes in the neighboring public's right to sunshine.

\subsubsection{Causation}

To become liable to another under tort law principles, an actor's conduct must not only be tortious in character but it must also cause harm to another's interest. ${ }^{46}$ Scholars from both common law and civil law countries have studied the causal connection in traditional torts and brought up various theories, but in practice, it is clear that these theories have problems of being implemented. So it is still not an easy task to establish the causation in environmental damages.

\subsubsection{Difficulties in establishing causal link for environmental damages}

Damage arising from environmental torts constitutes a form of indirect consequential harm. Thus, the causal connection between the allegedly tortious conduct and the alleged consequential harm can be undermined by intervening factors or other possible causes. The industrial revolution led to a rapid increase in development with the result that it became increasingly difficult for a victim to determine which of the pollutants should be responsible for the harm he suffered. In the postindustrial revolution era, there is hardly only one possible candidate for the source of environmental pollution; instead, the public has found themselves surrounded by belching chimneys and overflowing drainpipes. It is quite common that there are a number of different industries within one area, each producing different substances. Undoubtedly, scientific techniques have progressed rapidly in the past decades; however, it is still often extremely difficult to establish causation since sometimes even the latest scientific knowledge and techniques are still not capable of isolating the individual elements and tracing them to their respective sources. Just as Michael Garvey, a famous British lawyer, stated in giving evidence to a Select Committee on Noxious Vapors, that it was almost

\footnotetext{
${ }^{39}$ Id, at 174.

${ }^{40}$ Simon Deakin, Angus Johnston, and Basil Markesinis, Markesinis and Deakin's Tort Law, at 42, Clarendon Press (5th ed., 2003).

${ }^{41}$ Id, at 96.

${ }^{42}$ Id, at 96.

${ }^{43}$ Alcock v. Chief Constable of South Yorkshire, [1992] 1 A.C. 310. In this case, the relatives and friends of spectators who were crushed to death inside a football stadium as a result of police negligence brought actions for damages based on psychiatric illness suffered in reaction to the event. The court held that the plaintiffs should get compensations for the psychiatric damage.

${ }^{44}$ Eight World Well-known Environmental Hazards Incidents,

http://bbs.hitfm.cn/lofiversion/index.php/t43381.html. In 1961 in Yokkaichi, Japan, the exhaust gas from the smelting of petroleum and industrial fuel caused serious air pollution, resulted in a sharp increase of respiratory diseases, especially asthma. This incident is regarded as one of the prominent environmental issues.

${ }^{45}$ Cao Mingde, Huanjing Qinquanfa [Environmental Tort Law] at 174.

${ }^{46}$ REST 2d TORTS §9 (1965).
} 
impossible to establish liability because of "the difficulty of selecting any one of those effluvia and tracing it up to its source, so as to bring it home to manufacturer by legal evidence. We have always been defeated on this point. ${ }^{47 "}$ Admittedly, with the improvement of science, increasingly complex links between latent toxic substances and diverse kinds of health problems have been discovered. However, it is one thing to discover a possible connection, it is quite another to provide sufficient proof of the link to establish liabilities.

\subsubsection{Establishing causation for environmental damages}

In some environmental pollution cases, a toxin is often only one of a number of possible causes for a particular illness. However, even a small dose of this certain toxin may increase the incidence of certain illnesses; this is referred to as the "stochastic effect" $^{\text {"48 }}$. This fact is already beginning to challenge the existing legal tests for establishing causation.

\section{a. Causal Link in Traditional Tort}

The actual cause and the proximate cause inquiry lie at the core of the causation element in traditional tort. The actual causation is important in the plaintiff's prima facie case. Given the preponderance of the evidence standard of proof, this means that the plaintiff must prove that it was more probable than not that the defendant's conduct functioned as a cause of the plaintiff's injury. ${ }^{49}$ This causation is usually guided by a particular legal standard. This standard is known as the but-for test, also called the "sine qua non" or "counterfactual" test. ${ }^{50}$ In U.S. jurisdictions, the butfor test is the predominant test for an actual causation. ${ }^{51}$ Under the but-for test, the claimant must prove the existence of a causal connection on the balance of probabilities, which is taken to mean a likelihood of more than 50 per cent. If the court finds that it was just as likely that the damages would have occurred without the defendant's conduct, the action will fail even if there is an admission of fault.

The primary issue posed by proximate cause doctrine is whether there is something about the causal link between defendant's conduct and plaintiff's harm that warrants freeing the defendant from responsibility for that injury notwithstanding that connection ${ }^{52}$. In other words, it indicates that liabilities should attach for conduct that has caused the harm only if that conduct is sufficiently near to the harm either in time or space. A famous case under this theory is Moershigelafu v. Long Island Railway Corporation ${ }^{53}$. The accident occurred in August, 1924, in the New York Long Island Railway station. The plaintiff Mrs. Moershigelafu and her daughter were waiting on the platform for their train. Meanwhile, there was another train to a different destination starting to move. Two passengers late for that train began to run in order to catch it. One of them jumped into the train with ease; while the other eventually made it but nearly fell down. A staff on the platform tried to gave him a hand by pushing him on the back. At that time, the passenger's backpack that contained fireworks dropped on the railroad and exploded. The explosion blew down several signposts along the platform, and some of the flying debris injured Mrs. Moershigelafu. Mrs. Moershigelafu brought a lawsuit against New York Long Island Railroad Corporation, and asked for compensation. The court held that the Corporation was not liable for Mrs. Moershigelafu's injury because the staff's pushing was an indirect cause that was too remote from the injury in the causal chain.

\footnotetext{
${ }^{47}$ Select Committee on Noxious Vapors (1982), Minutes of Evidence 23, Q 238.

${ }^{48}$ Mark Wilde, Civil Liability for Environmental Damage, A Comparative Analysis of Law and Policy in Europe and the United States, Kluwer Law International (2002).

${ }^{49}$ John C.P. Goldberg, Anthony J. Sebok, Benjamin C. Zipursky, Tort Law, Responsibilities and Redress, NSPEN Publishers (2004).

${ }^{50}$ Id.

${ }^{51}$ In certain situations, however, courts employ an alternative test known as the substantial factor test.

${ }^{52}$ Simon Deakin, Angus Johnston, and Basil Markesinis, Markesinis and Deakin's Tort Law, at 42, Clarendon Press (5th ed., 2003).

${ }^{53} \mathrm{http}: / /$ dzl.legaltheory.com.cn/info.asp?id=9083
} 


\section{b. Causal Link in Environmental Tort}

Even though the actual cause and proximate cause theories have well functioned in traditional torts for centuries, difficulties arise when people try to apply those standards into establishing environmental torts. Due to the limitations of science and technology, it is hard to trace the sources of the pollution and find out the actual cause of the environmental damage. Even if explanations of the events leading up to the harm are found, it is still quite troublesome to prove causation with epidemiological and other toxicological evidence with the threshold set by the but for test, or to say, the more-likely-thannot standard. To make it simple, suppose in City A, one would expect to see 10000 cases of asthma over a ten-year period. But ever since the air has been polluted and contained toxins from the smelting of petroleum and industrial fuel, the residence in City A now experience a $10 \%$ increase in their risk of developing asthma. Therefore, instead of 10000 cases of asthma every ten years, one would find 11000 cases. This means that 1000 out of the 11000 cases are attributable to the air pollution. The ratio of developing asthma attributable to the air pollution is only $9.1 \%$, dividing 1000 by 11000 . But since no more than $10 \%$ of individuals have asthma as a result of the air pollution and this rate is far from $51 \%$, nobody could satisfy the more-likely-than-not standard of causation. When toxins that caused environmental damages do not have high attributable fractions, the probabilities fail to satisfy the more-likely-than-not standard, and cannot lead to successful tort litigation.

Since in environmental tort litigation, the morelikely-than-not threshold obviously has flaws, such a standard should be abandoned in favor of "conjecture causation." ${ }^{154}$ Under this standard, a victim only needs to show some signs which indicate that there is a connection between his damage and the tortious conduct. Courts are much likely to suppose that the connection does exist unless the alleged individual or company can prove that it has nothing to do with the environmental harm. This represents a move away from traditional theories that emphasize possibilities and ignore the weakened status of victims in the environmental damages.

In the U.S, there is another notion of causation which is called probabilistic causation. It means imposing liability "in proportion to the person according to the probability of causation, or the attributable fraction of disease." ${ }^{55}$ Within the last few years, courts have slowly adopted the standard of probabilistic causation ${ }^{56}$. There have been quite a few major settlements based on the notions of probabilistic causation. ${ }^{57}$

The new threshold in environmental torts, either conjecture causation or probabilistic causation, eliminates a great deal of the concern about the suits brought by many people who are exposed to environmental toxins, but who would today fail to reach the more-likely-than-not standard. It is likely to become a major part of the positive theory of environmental litigation.

\section{c. Burden of Proof}

In traditional tort, the demands of establishing a causal link place a heavy evidentiary burden on the plaintiff. ${ }^{58}$ In the conjecture causation theories discussed above, such burden of proof shifts to the defendant. The rationale for doing this lies in the fact that a plaintiff in an environmental tort case usually faces an inherent difficulty in finding evidence which can establish absolutely that the damage is attributable to one potential source of harm rather than another.

Some may argue that this shift of burden theory appears to be a little unfair to the defendants;

\footnotetext{
${ }^{54}$ See Huanjingfa Yuanli [Principles of Environmental Law] 157, Fudan Press, ( Lv Zhongmei ed., 1st ed., 2007).

${ }^{55}$ Troyen A. Brennan, Environmental Torts, 46 Vand. L. Rev. 1 (1993). at 62.

${ }^{56} \mathrm{Id}$.

${ }^{57}$ See Habitants Against Landfill Toxicants v. City of New York, 15 Envtl. L. rep. (Envtl. L. Inst.) 20937 (N.Y. Sup. Ct. May 20, 1985); Ayers v. Township of Jackson, 525 A. 2d 287 (N.J. 1987); Merry v. Westinghouse Elec. Corp., 648 f. Supp. 847 (M.D. Pa. 1988).

${ }^{58}$ Simon Deakin, Angus Johnston, and Basil Markesinis, Markesinis and Deakin's Tort Law, at 42, Clarendon Press (5th ed., 2003).
} 
however, considering the superior resources possessed by defendants, providing evidence to prove that a defendant is innocent of the environmental damage would not be as burdensome as it is for a plaintiff who suffers from inherent evidentiary difficulties. Besides, to do so may impose a strong incentive for careful behaviors on the part of defendants.

Up to now in China, e.g. there are no statutes or regulations about the shift of burden or conjecture causation. In the latest version of China's Civil Procedure Law, which is modified on October 28, 2007, and becomes effective on April 1, 2008, it is regulated that any person who brings a civil lawsuit to court has the burden of proof. ${ }^{59}$ However, in the Opinions about the Applications of Civil Procedure Law in People's Republic of China, article 74 gives a specific statement about the shift of burden: in the lawsuit of environmental damages, defendant who denies the committing or involvement of the tortious conduct has the burden of proof. ${ }^{60}$

Moreover, the conjecture causation theory has been widely admitted and applied in the practice of environmental pollution cases in China. It was first applied in the case of Wang Juan V. Qingdao Chemical Plant as early as $1980 .^{61}$ The fact of the case is that on July 1 , due to the lightening strike on the wirings in Qingdao Chemical Plant, a great deal of chlorine leaked out of a container. Approximately ten people living near the plant developed symptoms of toxicosis. Ms. Wang Juan was one of them. Her residence was within the area seriously polluted by chlorine. The night of the accident, Ms. Wang suffered from bronchial asthma because she breathed in excessive amounts of chlorine. Despite a favorable recovery after a long period of hospital treatment, the asthma broke out aperiodically. In the April of 1980, Ms. Wang brought a lawsuit against Qingdao Chemical Plant. Qingdao Chemical Plant refused Ms. Wang's compensation request claiming that chlorine toxicosis had nothing to do with bronchial asthma, and thus, Wang Juan's suffering from aperiodical asthma was unrelated to the leak of chlorine. The intermediate court in the city of Qingdao held that the plant was liable for Wang Juan's injury because there was a causal link between Ms. Wang's suffering and the leak of chlorine. The causation was established because: (1) a large quantity of epidemiologic evidence attested to the consequence between the inbreath of chlorine and the developing of asthma; (2) the hospital thought that Wang Juan's developing of asthma could be caused by inbreathing of too much chlorine or other materials; (3) Wang Juan had never had bronchial asthma before and neither had her close relatives; and (4) Wang Juan developed asthma just after the leak of chlorine from Qingdao Chemical Plant. This is an exact example of the application of conjecture causation and this is also the very first case concerning environmental civil liability in China.

\subsubsection{Causation for damage vs. causation for scope of compensation}

Causation does not only exist between tortious conduct and the damage but also lies between the conduct and remedy. Confirming causation for the scope of compensation is the next step after establishing causation for harm. To set up the connection between the conduct and the scope of compensation, it seems to be unfair to the defendants who have been alleged for the environmental torts if the conjecture causation standard is again applied. As a consequence, to determine how much a defendant is liable for the damage, the standard of foreseeability is a good choice. In other words, the compensation for the damage caused by the environmental tortious conduct has to be foreseeable, and within a reasonable scope.

\footnotetext{
${ }^{59}$ Civil Procedure Law of People's Republic of China, $\$ 6$, article 64 (October 28, 2007) http://blog.sina.com.cn/s/print_48fe98ed01000czp.html

${ }^{60}$ Opinions about the Applications of Civil Procedure Law in People's Republic of China, article 74 (July 14, 1992)

http://www.mslv.net/yljf/Article_Show.asp?ArticlelD=160

${ }^{61}$ Wang Juan v. Qingdao Chemical Plant (1980) http://www.riel.whu.edu.cn/show.asp?ID=1498.
} 


\subsubsection{Standards of Environmental Tort Liability}

Environmental tort, compared to traditional tort, has some unique features. However, because the former originates from the latter, the two types of liability share common features. For this reason, to study the standards of environmental tort liability, it is necessary to analyze various criteria of traditional tort liability.

\subsubsection{Criteria of liability}

Criterion of liability refers to the standard used to determine whether someone's conduct is tortious or not. ${ }^{62}$ This is one of the fundamental questions when deciding the existence of tort liability. ${ }^{63}$ The changing of the criteria of liabilities is the main line of the development of torts, which starts from singleness and develops into pluralistic concepts.

\subsubsection{Absolute liability standard}

Once someone is affirmed to be the person who causes harm, the harm itself is sufficient to make that person liable for his conduct. ${ }^{64}$ Under this circumstance, no other proof is needed. In a word, if there is harm, there is liability. This criterion was prevailing in the early age of human society, namely, the time before industrial society. ${ }^{65}$

\section{a. Fault-based Liability Standard}

Fault-based liability is "based on some degree of blameworthiness. ${ }^{166}$ It is also termed fault liability ${ }^{67}$ Fault is the only factor that judges have to take into consideration when deciding if the subject of the conduct is a tortfeasor or not. In another word, it does not matter that the subject acts either intentionally or negligently. Once there is fault, there is liability. This criterion developed right after the germination of capitalism. ${ }^{68}$ It completely replaced harm liability theory in the movement of Roman Law Revivification, which took place at the beginning of the $11^{\text {th }}$ century. ${ }^{69}$ By the $19^{\text {th }}$ century, the fault liability standard had obtained the dominant place in the criteria of liability in most capitalist countries, such as France, England, and Germany. ${ }^{70}$

\section{b. Constructive Fault-based Liability Standard}

This standard means when defendant cannot prove that he acts without any fault, he should be liable for the damage he causes. When the standard applies, the burden of proof shifts to the person who is sued for his tortious conduct. It changes the principle in traditional torts that plaintiff has to prove his claim. The aim of applying such a standard is to better protect the people harmed by tortious conduct.

\section{c. Strict Liability Standard}

Once this standard is applied, liability does not "depend on actual negligence or intent to harm.".71 Instead, it is based on "the breach of an absolute duty to make something safe." ${ }^{.72}$ Strict liability usually applies "either to ultrahazardous activities or in products-liability cases." ${ }^{173}$ It is also called liability without fault in some countries. The main idea of this principle originates from "Reasonable Share of the Calamity", which is brought by a German scholar, Professor Esser. ${ }^{74}$

\footnotetext{
${ }^{62}$ Zhang Xinbao, Zhongguo Qinquanxingweifa, [Tort Law in China], 42, Social Science Press (1998).

${ }^{63}$ Id.

${ }^{64}$ Cao Mingde, Huanjing Qinquanfa [Environmental Tort Law] 146, the Legal Press (2000).

${ }^{65}$ Id. at 147.

${ }^{66}$ Black's Law Dictionary (8th ed. 2004)

${ }^{67}$ Id.

${ }^{68}$ Cao Mingde, Huanjing Qinquanfa [Environmental Tort Law] 147, the Legal Press (2000).

${ }^{69} \mathrm{Id}$.

${ }^{70}$ Id.

${ }^{71}$ Black's Law Dictionary (8th ed. 2004)

${ }^{72}$ Id.

${ }^{73}$ Cao Mingde, Huanjing Qinquanfa [Environmental Tort Law] 148, the Legal Press (2000).

${ }^{74}$ Miao Wanwen, Lun Huanjing Qinquan de Guize Yuanze [A Discussion of Liability Criteria in Environmental Torts],

http://zhidao.baidu.com/question/13661078.html
} 


\section{d. Equitable Liability Standard}

When neither of the two parties has fault in the damage, sometimes courts may apply this standard. ${ }^{75}$ The disparity of assets owned by each party and other such factors will be taken into consideration in this situation. ${ }^{76}$ And courts order the tortfeasor to compensate for the property loss suffered by the victim. ${ }^{77}$ Equitable liability standard is quite controversial among academics, since most scholars believe that it causes uncertainty in outcomes. But it is still quite popular in the legal practice in China. $^{78}$

\subsubsection{Liability standards in environmental torts}

Liability criteria in environmental torts are experiencing a change from a subjective standard to an objective standard, or specifically speaking, from fault-based liability to strict liability standard.

In the past, when an environmental tort case was presented in front of a court, judges most of the time were unwilling to accept that environmental pollution is dangerous. ${ }^{79}$ Therefore, judges usually applied the fault-based liability standard. As a consequence, the plaintiff was required to prove that the care exercised by the polluter was below a reasonable standard. As discussed above in "Characteristics of Environmental Torts as Compared to Traditional Torts", there is frequently a certain latency period between the exposure to the pollution and discovery of injury, and by the time of the lawsuit, much of the important evidence may be unavailable to the plaintiff. This resulted in a tremendous burden for the victims in environmental pollution.

It did not take long before people realized that environmental pollution was extremely harmful.
Now courts tend to be friendly to potential plaintiffs in environmental litigation, and the strict liability standard was brought into environmental tort cases. ${ }^{80}$ As opposed to the fault-based liability standard, which operates on subjective intentionality, strict liability standard heavily relies on the objective fact of damage or injury. It helps courts to identify the best preventer of injury and to affix liability, ${ }^{81}$ especially when the defendant has greater information than the courts and the plaintiff.

In common law countries, an increasing number of environmental pollution victims have used nuisance or "engaging in extremely dangerous activities" as the cause of action instead of intentional tort or negligence, because based on these causes of action, courts will apply the strict liability standard to the defendants. Even though it is quite rare, courts might consider the subjective conditions of a defendant- intent to do or negligently causes the harm in a nuisance case, in a lawsuit brought based on extremely dangerous activities, courts will definitely impose strict liability standard for the injury or damage.

The first case that applied the strict liability standard in a lawsuit brought for extremely dangerous activities is Rylands v. Fletcher in $18688^{82}$ Defendant Fletcher occupied land near a coal mine which was operated by the plaintiff Rylands. Several of the coal seams extended to Fletcher's land. Fletcher did not notice the seams because they were under his land, and Rylands totally forgot about these coal seams since they had been previously worked on and once the work was done, the tunnels and shafts had been cut off. Fletcher employed a third person to build a reservoir on his land to provide water for his mill. During the construction, the third person discovered the seams under Fletcher's land, but he did not inform Fletcher nor did he block up the shafts. When

\footnotetext{
${ }^{75}$ Wang Xuetang, Cong Yiqi Anli Tan Gongping Zeren Yuanze de Cunzai Biyaoxing [the Necessary Existence of Equitable Liability StandardLearning from a Case], http://www.dffy.com/sifashijian/sw/200512/20051225212652.htm, Dec 25th, 2005, last visit on Jan 25th, 2008.

${ }^{76}$ Id.

${ }^{77}$ Id.

${ }^{78}$ Id.

${ }^{79}$ W. Page Keeton, et al., Prosser and Keeton on the Law of Torts, 547-48 (West, 5th ed. 1984).

${ }^{80}$ Reasons for bringing strict liability standard to environmental tort cases will be discussed in detail in the next subtitle.

${ }^{81}$ See Guido Calabresi and Jon T. Hirschoff, Toward a Test for Strict Liability in Torts, 81 Yale L.J. 1055-60 (1972).

${ }^{82}$ Rylands v. Fletcher, L.R. 3 H.L. 330 (1868).
} 
the reservoir was filled with water, the water passed through the shafts beneath and flooded Rylands' coal mine and caused damage. Rylands sued on the grounds of Fletcher's negligence. Fletcher succeeded in the Court of Exchequer and Rylands appealed to the Exchequer Chamber. Eventually the case went to the House of Lords and Fletcher was held liable for the damage. The issue in this case was whether an occupier who keeps a potentially dangerous substance only needs to take reasonable care. Lord Blackburn J., who delivered the judgment of the court said, "the person who for his own purpose brings on his land [...] anything likely to do mischief if it escapes, must keep it at his peril and is prima facie answerable for all the damage which is the natural consequence of its escape." ${ }^{83}$ Lord Cairns added to the rule that it only applied to a "non-natural" use of the land.

The decision in this landmark case created a new standard. The word "natural" has since been extended to mean "ordinary", and "abnormally dangerous" has been divided into the group of "nonnatural". ${ }^{84}$ The rule in this case is the most-often quoted example of strict liability. Moreover, ever since this case, more other activities that result in environmental damages have also been the subject of strict liability standard.

Generally speaking, when a strict liability standard is imposed, activities must pose significant foreseeable risk even when reasonable care is exercised. Detailed requirements of this cause of action may vary across jurisdictions. For instance, in some jurisdictions, the activity must not be a matter of common usage, but in others, common usage definitely is not an absolute requirement. ${ }^{85}$
In civil law countries, similar changes in liability criteria also occurred, although almost a century after changes in common law countries. In Germany, for example, prior to the effective date of the Environmental Liability Act 1991, a plaintiff always had to establish fault under the Civil Code with respect to any damage or injury caused by pollution. Before the introduction of Environmental Liability Act 1991, the strict liability standard only existed in very limited areas, such as mining, nuclear reactors, and other similar industries that are likely to release hazardous substances into the environment. It was not until the Sandoz fire ${ }^{86}$ in 1986 which caused transboundary pollution of the Rhine from Basle in Switzerland to Rotterdam in the Netherlands did the German government realize the severity of modern environmental pollution and the necessity of the strict liability standard, not just the most harmful. This eventually resulted in the broad application of strict liability standard in environmental tort in Germany. ${ }^{87}$

In the aspect of international conventions and treaties, although various standards may be found in the environmental tort regimes, ${ }^{88}$ the strict liability standard is increasingly preferred in current international practice. The Convention of the Council of Europe on Civil Liability for Damage Resulting from Activities Dangerous to the Environment is a good illustration of trend. ${ }^{89}$ Indeed, many experts commented that this trend should be encouraged because "given the difficult burden of proof to establish fault and its subjective intentionality, it is only natural that the fault-based is being increasingly questioned in the context of environmental damage."

\footnotetext{
${ }^{83}$ Id.

${ }^{84}$ Cao Mingde, Huanjing Qinquanfa [Environmental Tort Law] 149, the Legal Press (2000).

${ }^{85}$ See Cities Serv. Co. v. Florida, 312 So. 2 d 799 (Fla. Dist. Ct. App 1975). In this case, the court imposed strict liability for damage caused by slime reservoir, even though the reservoir seemed to be common in Florida.

${ }^{86} \mathrm{http}: / /$ www.chinaenvironment.com/view/ViewNews.aspx?t=News_1\&k=19861101161300734

${ }^{87}$ Specific provisions relating to strict liability standard are provided in Section III.

${ }^{88}$ Patricia W. Birnie \& Alan E. Boyle, International Law and the Environment, 139-48 (1992).

${ }^{89}$ Council of Europe, Convention on Civil Liability for Damage Resulting from Activities Dangerous to Environment, June 21, 1993, 32 I.L.M. 1228 (1993).

${ }^{90}$ Francisco Orrego Vicuna, Final Report Prepared for the Eighth Committee of the Institute of International Law by the Rapporteur on the Subject of Environmental Responsibility and Liability, at 286, 10 Geo. Int'I Envtl. L. Rev. 279.
} 


\subsubsection{Reasons for the change of liability standards}

The change from fault-based liability to a strict liability standard is occurring relatively quickly in the environmental tort regime compared to that in traditional torts. The reasons are as follows:

\section{a. The limitation of Modern Science and Technology}

The existing achievement of science and technology cannot help people precisely predict all kinds of environmental pollution and totally keep away from property damages or personal injuries caused by the pollution. The sources of pollution are mostly from modern enterprises who engage in highly dangerous activities. Even if these enterprises scrupulously follow the specific measures specially designed for them; and even if these enterprises have no fault in the pollutions, they are still highly likely to cause serious damages or injuries to people. If courts apply a fault-based liability standard, it is impossible to provide valid remedies to those victims suffering in the pollutions.

\section{b. The Characteristic of Environmental Tort}

As indicated above, environmental tort produces subtle harm. In most circumstances, victims can neither prove what the polluters exactly discharge nor the causal connection between the discharge and the harm; sometimes, they are even not able to identify the polluters, let alone their subjective intentionality. Additionally, the majority of victims are ordinary city residents and peasants who are less likely to be equipped with knowledge of science and technology. If fault-based liability is still applied, then victims have the burden to prove defendants' fault in the environmental damage. This often serves to deprive those victims of their environmental rights. Meanwhile, such a liability standard encourages polluters, and leads to more serious damages.

\section{c. The Essence of Strict Liability Standard}

The nature of strict liability standard lies in the theory of "reasonable share of calamity". ${ }^{91}$ In some sense, the profits obtained by the enterprises who have caused environmental pollutions are established on the basis of polluting the environment and bringing damages to other people. Thus, they should not only be responsible for the fault but also for the risk of the activities they are involved in. At the same time, compared to the victims, enterprises have an advantage in the economy, and they usually pass their liabilities to the society through price and insurance. Therefore, potential victims' interest is protected and meanwhile operators do not bear a huge burden. This seems like a win-win solution. It corresponds with the soul of civil law-fairness.

\section{d. The Consciousness of Responsibility}

Another purpose of applying strict liability is to enhance the enterprises' consciousness of responsibility, to urge them to give full attention to their activities, and to spur them to use the most updated techniques and devices to prevent the environmental pollutions.

\subsubsection{Concerns about using strict liability standards in environmental torts}

Although according to the above discussions, the strict liability standard does offer a relatively solid ground to build an effective environmental tort regime, it does not necessarily mean that such an objective standard is definitely free from legal difficulties and criticism. ${ }^{92}$

Some say that strict liability results in more law suits. $^{93}$ In environmental torts, defendants usually have an information advantage compared to the courts and plaintiffs. It may cost a lot of time and

\footnotetext{
${ }^{91}$ Lun Wuguocuo Zeren Yuanze [A Discussion on Strict Liability Standard], Falv kuaiche, www. Lawtime.cn, http://sunhai.lawtime.cn/shzhishi/2006102041039_3.html

${ }^{92}$ W. J. Ovwerkerk, Environmental Liability from the Perspective of an Operator: Council of Europe Draft convention on Civil Liability for Damage Resulting from Activities Dangerous to the Environment, in Transnational Environmental Liability and Insurance 85-9 (Kroner ed., 1993).

${ }^{93}$ See William M. Landers and Richard A. Posner, The Economic Structure of Tort Law 64-6 (Harvard, 1987).
} 
money to gather enough information in order to balance the benefits between the two parties. By using a strict liability standard, information costs certainly will decrease. However, it simultaneously leads to the increase of the number of claims. Since the "obstacle" is no longer there, courts would be buried in environmental tort cases, many of which may be only with regard to insignificant damages.

Some also argue that strict liability may cause overdeterrence to certain businesses. ${ }^{94}$ The reason for this is that sometimes defendants have no idea that their products or activities are possible to cause environmental damages; and the application of strict liability standard totally excludes their defense of foreseeability. It is unfair to these people especially when they have already done a comprehensive research on their products or activities they engage in, and no risk has been predicted. Such over-deterrence is likely to result in excessive costs and financial burdens to the defendants most of whom are entrepreneurs and contribute a lot to the national economy. It might discourage them from investments and cause economic retrogression.

Admittedly, generalizing the use of strict liability would lead to rise of the claim cost and overdeterrence to defendants. Nonetheless, compared to the cost of environmental damages, these disadvantages seem to be tolerable. Protecting the environment is always the priority and every environmental toxin should be considered abnormally dangerous and worthy of strict liability standard. Meanwhile, certain measures may be taken to reduce the burden on the defendants and claim costs, and to help strict liability standard work better in the environmental tort regime.

\subsubsection{Defense Against Environmental Civil Liability}

Strict liability provides room for certain defenses. Otherwise, it would "lose its corrective functions and become a purely distributional device." However, if the scope for defenses is too great, the characteristics of strict liability would be watered down and the strict liability standard would be no different than the fault-based liability standard. Most defenses used in environmental torts are similar to those in traditional torts. Additionally, some new exemptions from environmental civil liability are becoming popular even though some of them are quite controversial.

\subsubsection{Conventional defenses}

As stated above, defenses against liability in traditional torts also fit in the scope of environmental torts. These defenses can be divided into the following categories: force majeure, injured party's own fault, and third party fault.

\section{a. Force Majeure}

Force majeure is a French word meaning "a superior force" or "greater force." It refers to "an event or effect that can be neither anticipated nor controlled." "96 It essentially frees one or both parties from liability when an extraordinary event or circumstances beyond the control of the parties occurs and causes personal injuries or property damages. The term "Force majeure" includes both acts of nature, such as flooding, earthquake, volcano, and acts of people, such as war, strike, riot, and crime.

\footnotetext{
${ }^{94}$ See Beshada v. Johns-Manville Prods. Corp., 447 A. 2 d 539, 540 (N.J. 1982).

${ }^{95}$ Mark Wilde, Civil Liability for Environmental Damage, A Comparative Analysis of Law and Policy in Europe and the United States 231, Kluwer Law International (2002).

${ }^{96}$ Black's Law Dictionary (8th ed. 2004), force majeure.
} 
Many common law countries and civil law countries allow defendants to invoke force majeure as a defense to liability as long as it has a causal connection with the environmental tort. ${ }^{97}$ In modern international practice, exemptions based on armed conflict, terrorism or a natural disaster of an exceptional, inevitable and irresistible character, have often been accepted in environmental regimes and other liability arrangements. ${ }^{98}$ However, such exemptions require comprehensive drafting since they often relate to additional issues. For example, with respect to war, it has been noted that only the victims should be entitled to use this event as a defense against liabilities for the environmental damages. Then, what also needs to point out in the conventions is how to define a victim and an aggressor. At least, it has to be coherent with other international conventions that have already given a definition to "victim" and "aggressor" in a war. ${ }^{99}$

\section{b. Injured Party's Own Fault}

Injured party's own fault can be further divided into injured party's intention and contributory negligence. In the theory of injured party's intention, if the injured party intentionally exposed himself to the hazardous substances produced by the defendant, the defendant would be held not liable for the injury and compensation would be denied. For instance, Mr. P learned from a notice on a newspaper that one of the rivers in town had been polluted by a garbage disposal plant $C o$. D, and the water was no longer safe for use. Nonetheless, he still went fishing in that river, and cooked and ate the fish he caught. In the end, he got sick. Mr. P brings a lawsuit against $\mathrm{Co}$. D asking for compensation for his injury. Court will not order Co. D to compensate
Mr. P since he intentionally injured himself in the environmental pollution. Of course, $\mathrm{Co}$. $\mathrm{D}$ is liable for the water pollution, but this is different from being liable for Mr. P's sickness.

With respect to contributory negligence, if the plaintiff contributed to the damage by his negligence, compensation may either be reduced or denied altogether. ${ }^{100}$ This defense has been codified in some countries' environmental statutes, such as in German Environmental Liability. On the other hand, some legal experts reject contributory negligence as a full exemption from environmental tort liabilities, arguing that it can only be used for a partial reduction of liabilities. ${ }^{101}$ In China, only the Water Pollution Prevention Act has mentioned that contributory negligence can be used as a partial exemption, while other environmental statutes and regulations make no such allowances.

\section{c. Third-Party Fault}

If an environmental tortfeasor successfully defends himself based on third-party fault, he may either get a full exemption or a partial reduction of liabilities. There are different requirements of proof in different countries or international conventions. Take China for example, in its Marine Environment Protection Act, article 90 says that "if pollution is caused solely by the third party, either intentionally or negligently, the third party is liable for the damage and compensation." ${ }^{102}$ Article 55 (3) in China's Water Pollution Protection Act also provides a similar regulation. ${ }^{103}$ The European Commission's proposal of a Community Directive concerning Civil Liability for Damage Caused by Waste of September 1 , 1989 provides that the environmental tortfeasor

\footnotetext{
${ }^{97}$ Patrick Thieffry, Environmental Liability in Europe: the European Union's Projects and the Convention of the Council of Europe 1087, 28 Int'I Law. 1083 (1994).

${ }^{98}$ Francisco Orrego Vicuna, Final Report Prepared for the Eighth Committee of the Institute of International Law by the Rapporteur on the Subject of Environmental Responsibility and Liability 296, 10 Geo. Int'I Envtl. L. Rev. 279.

${ }^{99}$ This point will be fully discussed in Section III.

${ }^{100}$ Patrick Thieffry, Environmental Liability in Europe: the European Union's Projects and the Convention of the Council of Europe 1087, 28 Int'I Law. 1083 (1994).

${ }^{101}$ Huanjingfa Yuanli [Principles of Environmental Law] 193, Fudan Press, ( Lv Zhongmei ed., 1st ed., 2007).

${ }^{102}$ Zhonghua Renmin Gongheguo Haiyang Huanjing Baohu Fa (1999 Xiuding), [Marine Environment Protection Law of People's Republic of China (revised in 1999)]. Zhongguo Fayuan Wang, http://www.chinacourt.org/flwk/show1.php?file_id=34197

${ }^{103}$ Zhonghua Renmin Gongheguo Shui Wuran Fangzhi Fa (1996 Xiuding), [Water Protection Act of People's Republic of China (revised in 1996)], Zhongguo Wang, http://www.china.com.cn/chinese/huanjing/75543.htm.
} 
shall not be liable for the damage if he is able to prove that "in the absence of fault on his part, the damage to the environment is the result of an act or omission of a third party that intentionally caused the damage."104 Later in 1993, the Convention on Civil Liability for Damage Resulting from Activities Dangerous to the Environment exonerates the polluter of all liabilities if he is able to prove that "the damage was caused by a third party acting with the intent to cause damage, despite safety measures appropriate to the type of dangerous activity in question." ${ }^{105}$

\subsubsection{Other defenses used in environmental torts}

A number of other situations have also been included on occasion as defenses.

\section{a. Self-defense}

The word "self-defense" is usually used in criminal law. It refers to the use of force to protect oneself from a real or threatened attack. ${ }^{106}$ Generally, a person is justified in using a reasonable amount of force in selfdefense if he or she believes that bodily harm is imminent and that force is necessary to avoid this harm. ${ }^{107}$ In many countries in the world, the justification is extended to include the defense of other persons or of one's property. This concept has shown up for a few times as a defense against liabilities for environmental damages. But until now, it is still quite controversial to introduce this concept to the environmental tort regime. Some scholars think it difficult to set up a clear boundary to what is selfdefense, while some professionals hold the opinion that to some extent, it might be an effective way to help reduce possibilities of environmental pollution. ${ }^{108}$

\section{b. Regulatory Compliance Defense}

A more controversial issue concerns whether a defense should be available when the polluter has carried out an activity in compliance with a specific order or compulsory measure from a public authority or from a license. In other words, could the existence of such reasons be regarded as a form of statutory authority? The answer provided by some countries is "No". There is a well-known case decided by Austrian Supreme Court. ${ }^{109}$ In the case, the court awarded the plaintiffs compensation for the damage to the paintwork of their cars, which was caused by emissions of iron oxide dust from the defendant's facility that had been licensed since 1979. The court's holding was famous because it said that the defendant could not escape liability simply by relying upon the fact that it had held a license for 15 years. In the opposite way, some international conventions appear positive to include this specific regulatory compliance defense. Article 8 of Convention on Civil Liability for Damage Resulting from Activities Dangerous to the Environment provides exemptions for the above defenses. ${ }^{110}$ Either side seems to have strong points to support its decision. This will be further discussed in Section III.

\section{c. The Development Risk Defense}

In environmental tort cases, sometimes a defendant might argue that particular toxins could not have been discovered based on the current state of science and technology at the time the harm occurred. This raises the issue of whether a "development risk" defense should be accepted. This issue is even more complex, since it is hard to define "current state". Does the defense still work if the scientific knowledge

\footnotetext{
${ }^{104}$ Proposed Directive on Civil Liability for Damage Caused by Waste, COM (89) 282 final, modified by Amended Proposal for a Council Directive COM (91)219. (1991).

${ }^{105}$ Convention on Civil Liability for Damage Resulting from Activities Dangerous to the Environment, art. 8(b). Lugano, June 21, 1993, Europ. T.S. 150, reprinted in 32 I.L.M. 1230 (1993).

${ }^{106}$ Bryan A. Garner, a Handbook of Basic Law Terms, West Group (1999).

${ }^{107}$ Id.

${ }^{108}$ See Cao Mingde, Huanjing Qinquanfa [Environmental Tort Law], the Legal Press (2000).

${ }^{109}$ Mark Wilde, Civil Liability for Environmental Damage, A Comparative Analysis of Law and Policy in Europe and the United States 223, Kluwer Law International (2002)

${ }^{110}$ Convention on Civil Liability for Damage Resulting from Activities Dangerous to the Environment, art. 8(b). Lugano, June 21, 1993, Europ. T.S. 150, reprinted in 32 I.L.M. 1230 (1993).
} 
exists somewhere but is not popular? When can a defendant exhausts its scientific research efforts in order to be judged to have taken enough safety measures? There is no doubt that this defense leaves much room to be regulated.

As a matter of fact, what kind of defense is allowed in environmental tort is not an issue of vital importance, as long as that defense strikes a balance between the distributional and corrective functions of tort. In any case, defenses for exemptions and reduction of liabilities must be considered in a very restrictive perspective since they may end up depriving the liability scheme of all its significance.

\section{d. Statutory Prohibition}

Statutory prohibition refers to the situation where a statute has expressly prohibited an environmental tort claim that might have otherwise existed in the common law. For example, in the U.S., some states have passed "Right to Farm" laws, which gave farmers immunity from any future nuisance suits against farms based on excessive air pollution, noxious odors, and etc.

\section{e. Regulatory Preemption}

Regulatory preemption is an additional complicating defense where a federal statute that creates a regulatory system, rather than a common law system, is found to have preempted state common law tort claims. This issue has arisen in the U.S. in the context of pesticide regulation, with the federal government in certain situations arguing that the Federal Fungicides, Insecticides, and Rodenticides Act have removed certain state common law liabilities.

\subsubsection{Remedies for environmental damages}

The imposition of environmental civil liability is generally used to serve two main functions: corrective justice and deterrence, while liability for monetary damages is the remedy most frequently applied to serve these functions, injunctive relief can also achieve the same goal.

\subsubsection{Monetary damages}

In an overwhelming majority of environmental tort cases, monetary damage is the remedy applied. Plaintiff is entitled to both general damages, like pain and suffering, and special damages, such as some out-of-pocket expense. Monetary damages cover property damages and personal injuries as well. Cases in which the environmental tort action results in the victim's psychological suffering, the victim can also ask for compensation.

Traditionally in tort, the precondition for awarding monetary damages is the existence of actual harm to the victim. However and as noted above, the long latent period of some diseases dictates that potentially harmful environmental exposure often occurs considerably before any physical harm manifests itself. This problem brings a question to environmental tort: should pollution operators also be responsible for creating individuals' fear of suffering disease in the future? For instance, Ms. $P$ experienced a hazardous exposure in an environmental pollution created by $\mathrm{Co}$. D a year ago. Up to now, she has not suffered from any physical harm. But medical monitoring for potential diseases caused by the exposure has been very costly. Under this circumstance, should Co. $D$ compensate Ms. $P$ for this cost even if the monitoring has not revealed or will not reveal any injury or disease? Some scholars have proposed recognition of a cause of action for tortious creation of risk. ${ }^{111}$ Some courts have relaxed the traditional restrictions and permitted such recovery under limited circumstances. ${ }^{112}$

\subsubsection{Injunctive relief}

There are many types of injunctive relief in torts, but the three most often used in environmental torts are stopping the nuisance, eliminating the danger, and

\footnotetext{
${ }^{111}$ See Glen O. Robinson, Probabilistic Causation and Compensation for Tortious Risk, 14 J. Legal Stud. 779 (1985).

${ }^{112}$ Kenneth S. Abraham, The Relation Between Civil Liability and Environmental Regulation: An Analytical Overview, 41 Washburn L.J. 379.
} 
restoring the environment to its former state. In some cases, they are used separately, while in some cases, they work together. Injunctions have been proven to be very effective and efficient as remedies in the environmental tort regime because they force the polluters to investigate cleaner technologies.

\subsubsection{Standing Requirements and Statutory Limitations}

\subsubsection{Standing requirements}

When the word "standing" is used as a legal term, it means "a party's right to make a legal claim or seek judicial enforcement of a duty or right." ${ }^{\prime \prime 13}$ In traditional torts, only those who have suffered some form of loss, such as personal injury or property damage, or an interference with the rights and benefits which flow from an interest in land have the right to sue. In environmental torts, a similar requirement applies. Generally speaking, standing to sue is restricted to individual who has suffered harm of the sort traditionally redressed by tort law. ${ }^{114}$ Then, there appears to be a serious defect. As there is no guarantee that the individual who has the right to sue would choose to pursue the matter, it is not an effective way to protect the environment. For instance, Mr. P owns an area of waste land. For quite a few years, he had no interest in the property since he did not feel like developing it. During this time, the land turned out to be an unofficial waste yard which had all kinds of polluting substances and toxins. The probable outcome would be Mr. P leaves the land as it is and the garbage keeps polluting the environment. Moreover, even if Mr. $\mathrm{P}$ finally chooses to bring a lawsuit, he may lack the necessary resources.

In order to minimize the negative impact of such standing requirements, some countries, like the U.S., extend to right to sue to non-governmental organizations, such as nonofficial environmental protection groups. Whereas many countries still limit the right to individuals and seem to have not ever considered extending standing in this manner. What is worth mentioning is that even with the existence of organizational standing, environmental groups do not have unlimited capacity to sue in the states. Even though environmental groups do have the ability to sue, at least one of the members needs to have standing to sue in order to raise the suit.

\subsubsection{Statute of limitations}

The term "statute of limitations" refers to "a statute establishing a time limit for suing or for prosecuting a crime, based on the date when the claim accrues." ${ }^{115}$ One of the purposes in setting a time limitation is to ensure that claims will be resolved while evidence is reasonably available and fresh. People tend to think that the longer the statutory limitation is, the less possible it is that the evidence is available and fresh. However, in environmental torts, this rule may not work well. Because of some of the special features shown by environmental tort discussed under subtitle $B$, it is not a bad idea to extend the statutory limitation in these cases.

Right now in most countries around the world, the time limitation is three years from the date on which the plaintiff knew or should have known of the damage suffered from the environmental pollution. Nevertheless, in some cases plaintiffs are likely to have trouble realizing the diseases they get from the pollution because of the long incubation period of the diseases. Even if they have realized the harm, they may have difficultities locating the source or the identity of the operator. How to solve this problem is also a "hot" issue.

From the brief overview of environmental civil liability, we may conclude that its distinctions from traditional tort have left many issues unsolved. If they are handled well, environmental damages may be effectively reduced and the right of individuals suffering from environmental pollutions will be well protected; if not, operators will keep polluting the

\footnotetext{
${ }^{113}$ Bryan A. Garner, a Handbook of Basic Law Terms, at 204, West Group (1999).

${ }^{114}$ See Frank B. Cross, Rethinking Environmental Citizen Suits, 8 Temp. Envtl. L. \& Tech. J. 55 (1989).

${ }^{115}$ Bryan A. Garner, a Handbook of Basic Law Terms, at 206, West Group (1999).
} 
environment, and bringing disasters to human beings remaining beyond the arm of civil liability.

\section{ENVIRONMENTAL CIVIL LIABILITY REGIMES IN THE U.S AND E.U}

Compared with traditional tort, environmental tort has many different features which challenge and expand upon traditional tort theory. Thus, it would be inappropriate to simply borrow and apply outdated, traditional tort analysis to environmental tort cases. Both common law and civil law countries have made and are making environmental laws and policies based on the individual circumstances existing in each country. In addition, since a large quantity of environmental pollution is transboundary, many countries around the world have established international or regional conventions with regard to environmental civil liabilities. To assess the wideranging approaches to environmental tort, this section will compare the environmental civil liability regimes in the U.S, and in the European Union.

\subsection{Environmental Civil liability System in the U.S.}

In the U.S, common law notions of tort theory as well as statutes and regulations establish civil liability for environmental damages. Generally speaking, any common law tort cause of action for physical injuries and property damages is potentially available in environmental tort actions. Statutory causes of action for the cost of environmental remediation are often available under statutes created by federal and state legislatures.

\subsubsection{Environmental civil liabilities under common law}

\section{a. Trespass and Nuisance}

The theory of trespass aims to protect an individual's right of to possess land. Recovery for monetary damages is available for actual physical invasions of property. Nuisance actions, like trespass actions, relate to individual rights of land possession, but extend these rights further, protecting the right to use or enjoyment of land. Nuisance theory traditionally provides remedies for a non-possessory interference like pollution, which is actionable for either personal injuries or property damages. $^{116}$

Common law nuisances are divided into public nuisances and private nuisances. The former affects the reasonable comfort and convenience of a class of subjects and the latter affects only particular individuals. Public nuisances usually have a wide-spread range, so it is difficult for one individual to demonstrate public nuisance as a cause of action; the entire community suffering from the public nuisance should take on the responsibility. Private nuisance claims are somewhat more complicated. Unlike public nuisance actions, statutory authority and prescriptive right are effective defenses to claims of private nuisance.

One of the important elements to establish nuisance is that the interference with the plaintiff's interest has to be unreasonable. ${ }^{117}$ However, unreasonable interference differs from unreasonable conduct. In some cases, even if the conduct is reasonable, the polluter is liable if the conduct constitutes a substantial unreasonable interference. When making a determination about whether or not the unreasonableness exists, courts take into account factors such as the location of the setting, the burden on the plaintiff and the history of that land use. ${ }^{118}$ To illustrate the analysis of these factors, consider two instances of air pollution of the same degree. One is in an industrialized neighborhood, while the other is in a rural area with no manufactu-ring history. The operator in the rural area is more likely to be held liable for nuisance because the courts would probably consider the location of the setting and the history of the land use as a significant factor in the reasonableness of the pollution.

\footnotetext{
${ }^{116}$ W. Page Keeton et al., Prosser and Keeton on Torts $\S 13$ (5th ed. 1984).

${ }^{117}$ W. Page Keeton et al., Prosser and Keeton on Torts $\S 87$ (5th ed. 1984)

${ }^{118}$ W. Page Keeton et al., Prosser and Keeton on Torts $\S 88$ (5th ed. 1984).
} 


\section{b. Negligence}

Negligence is "the failure to exercise the standard of care that a reasonably prudent person would have exercised in the same situation." ${ }^{.19} \mathrm{~A}$ cause of action for negligence is also potentially available in claims for environmental harm. Traditionally, proving negligence for environmental damages requires a plaintiff to demonstrate that (1) the polluter owed him a duty of care; (2) the polluter breached the standard of care imposed by that duty; (3) the harm that occurred was caused by the breach of the duty; and (4) it was a reasonably foreseeable consequence of the breach of duty. ${ }^{120}$

Because of the characteristics of environmental tort actions discussed in section II, such as difficulty determining polluters, unequal status of victims and operators, problems of identifying the injury and so forth, it is usually not easy for a claimant to prove elements of duty of care, damages and causation.

To satisfy the foreseeability requirement, a claimant must prove that at the time of the tortious conduct, the operator knew or should have known of the risk that his conduct could cause environmental harm. In a few claims, this is feasible. However, this is not always the case. Due to the long-term latency of many environmental torts, it often takes a while before the harm at issue materializes. Before manifestation of the harm, it is not possible to establish the causal link between the defendant's conduct and the environmental damages, not to mention the defendant's ability to foresee the risk.

Compared to the requirements set in a negligence case, the negligence per se doctrine, as codified in U.S statutes and regulations, treats the requirement of foreseeability in a flexible manner. In most jurisdictions in the U.S, the unexcused violation of an applicable statute or regulation is negligence as a matter of law. ${ }^{121}$ The cause of action is complete once a polluter violates the statutes or regulations, as the polluter essentially harms the same class of people protected by those laws. ${ }^{122}$ Foreseeability is no longer an element that needs to be met under this circumstance.

\section{c. Strict Liability}

Strict liability may be imposed for personal injuries or property damages caused by "extremely dangerous" activities. ${ }^{123}$ As discussed in section II, it was in the English common law case Rylands $v$. Fletcher was established. In that case, the courts said that building and occupying a reservoir is an abnormally dangerous activity. In the U.S, the range of abnormally dangerous activity has been greatly expanded, and thus, many activities resulting in environmental harm have fallen into the scope of abnormally dangerous activities and become the subject of claims for strict liability.

In Ashland Oil, Inc. v. Miller Oil Purchasing Co., et al., defendant, a waste disposal company, injected hazardous chemical waste into an oil pipeline, causing a fire and explosion. ${ }^{124}$ In the explosion plaintiff's refinery was badly damaged. Plaintiff sued defendant for disguising the industrial waste as a benign oil product and expelling it into the oil pipeline, thereby affecting interstate commerce. ${ }^{125}$ The trial court held that defendant was liable for its intentional involvement in an extremely dangerous activity under the theory of strict liability. ${ }^{126}$ The United States Court of Appeals affirmed the judgment of the trial court and agreed that the disposal of waste by introducing it into the oil pipeline was abnormally dangerous. ${ }^{127}$

In a similar state case, Valentine v. Pioneer Chlor Alkali Company Inc, the Supreme Court of Nevada

\footnotetext{
${ }^{119}$ Black's Law Dictionary (8th ed. 2004)

${ }^{120}$ David Hughes, Environmental Law 61 (2d ed. 1992).

${ }^{121}$ See Kenneth S. Abraham, The Forms and Functions of Tort Law (1977).

${ }^{122}$ See Kenneth S. Abraham, The Forms and Functions of Tort Law (1977).

${ }^{123}$ See Restatement (Third) of Torts, Chapter 4 Strict Liability $\$ 20$ (2005).

${ }^{124}$ Ashland Oil, Inc. v. Miller Oil Purchasing Co., et al., 678 F. 2d 1293 (5th Cir. 1982).

${ }^{125} \mathrm{Id}$.

${ }^{126}$ Id.

${ }^{127}$ Id.
} 
adopted the doctrine of strict liability for the release of liquefied chlorine into the environment. ${ }^{128}$ It held that the operation of a facility engaged in the manufacture, storage, and control of liquefied chlorine and chlorine gas, constituted an abnormally dangerous activity. ${ }^{129}$ As to the question how to decide that an activity involving chlorine is necessarily an "abnormally dangerous activity", judges highly recommended the approach taken in Erbrich Prod. Co., Inc. v. Wills, 509 N.E. 2d 850 (Ind. Ct. App. 1987). In the court's opinion, judges cited from Erbrich:

We of course recognize that chlorine gas, in its natural state, is dangerous. However, the fact that chlorine gas is dangerous is not determinative. When deciding whether to impose [strict] liability, we must not look at the abstract propensities or properties of the particular substance involved, but must analyze the defendant's activity as a whole. If the rule were otherwise, virtually any commercial or industrial activity involving substances which are dangerous only in the abstract automatically would be deemed as abnormally dangerous. This result would be intolerable. ${ }^{130}$

This case has a significant impact even although it is not as seminal as Rylands $v$. Fletcher since it primarily expounds upon the principles first established in Erbrich. Before Erbrich, to determine whether an activity is abnormally dangerous and whether strict liability should be imposed upon a defendant, six factors had to be satisfied: (1) existence of a high degree of risk of some harm to the person, land or chattels of others; (2) likelihood that the harm that results from it will be great; (3) inability to eliminate the risk by the exercise of reasonable care; (4) extent to which the activity is not a matter of common usage; (5) inappropriateness of the activity to the place where it is carries on; and (6) extent to which its value to the community is outweighed by its dangerous attributes. ${ }^{131}$ These factors were rather vague and needed to be more fact specific. The Supreme Court of Nevada helped to bring more specificity to the rules.

In Caporale, the Nevada Supreme Court held that the maintenance of a strict liability claim requires proof of three factors: (1) an instrumentality capable of producing harm; (2) circumstances and condition in its use which, irrespective of a lawful purpose or due care; (3) and a causal relation between the activity and the injury for which damages are claimed. ${ }^{132}$ In addition, a person who uses an intrinsically dangerous means to accomplish a lawful end, in such a way as will necessarily or obviously expose the person of another to the danger of probable injury, faces liability if injury results, even though he uses all proper care. ${ }^{133}$

Based on the above rules, the United States District Court for the District of Connecticut held in Albahary v. City \& Town of Bristol, that city landfill contamination was the subject of strict liability. ${ }^{134}$ In this case, plaintiff owned a parcel of land adjacent to the landfill operated by the town of Bristol. Defendant did not manage the landfill properly. ${ }^{135}$ The defendant allowed hazardous wastes and toxic substances to be dumped into the landfill, which resulted in the pollution and contamination of the soil, ground and water beneath plaintiff's land. ${ }^{136}$ Plaintiff claimed that his land had been "rendered undevelopable and had substantially declined in value because the contamination of the land's groundwater deprives it of its only source of potable drinking water."137 Judge Janet Bond Arterton delivered the Court's opinion that:

\footnotetext{
${ }^{128}$ Michela D. Valentine and Jack D. Valentine v. Pioneer Chlor Alkali Company Inc., 109 Nev. 1107 (1993).

${ }^{129} \mathrm{Id}$.

${ }^{130}$ Michela D. Valentine and Jack D. Valentine v. Pioneer Chlor Alkali Company Inc., 109 Nev. 1107 (1993) (citing from Erbrich Prod. Co., Inc. v. Wills, 509 N.E. 2d 850 (Ind. Ct. App. 1987) at 856.)

${ }^{131}$ Restatement (Third) of Torts, Chapter 4 Strict Liability $\$ 20$ (2005).

${ }^{132}$ Caporale v. C.W. Blakeslee and Sons, Inc., 175 A. 2 d 561 (D. Conn. 1961).

${ }^{133}$ Worth v. Dunn, 118 A. 467 (D. Conn. 1922).

${ }^{134}$ Albahary v. City \& Town of Bristol, 963 F. Supp. 150 (D. Conn. 1997)

${ }^{135}$ Id.

${ }^{136} \mathrm{Id}$.

${ }^{137}$ Id. at 152.
} 
Because hazardous materials are an instrumentality capable of producing harm, and because the circumstances and conditions of its disposal into a municipal landfill, irrespective of a lawful purpose or due care, involve a substantial risk of probable injury to the person or property of others, the court concludes that disposal of hazardous and toxic wastes at a landfill may constitute an abnormally dangerous or ultrahazardous activity sufficient to maintain a cause of action for strict liability, and in light of plaintiff's allegation that defendant allowed the discharge into the Bristol landfill of hazardous substances, plaintiffs are entitled to put forth evidence of the extent to which disposal of hazardous materials was allowed and encouraged at the landfill. As well as the toxic nature of the hazardous wastes plaintiffs allege were disposed of there. ${ }^{138}$

These three cases can be regarded as the reflections of how the theory of strict liability is applied and developed in environmental damages.

\subsubsection{Environmental Civil Liabilities under Statutes}

Environmental civil liabilities are being regulated in various statutes in the U.S, such as in the Clean Water Act and Resource Conservation and Recovery Act (RCRA). However, these acts do not provide a mechanism to fund remediation for environmental damages. The most typical and famous act is the Comprehensive Environmental Response, Compensation and Liability Act of 1980 ("CERCLA"), also known as the "Superfund" Act. ${ }^{139}$ Its goal is to create a system which can help to accomplish the remediation of sites containing hazardous waste that pose a threat to the environment or public health. Many states have their own "mini-Superfund", which are quite similar to CERCLA, applying to sites that are not within the scope of the federal regime.

\section{a. ABrief History of CERCLA}

Love Canal is a well-known name to most environmental lawyers in the United States, since it was the setting of the most highly publicized events of environmental pollution that the U.S. has ever known. In the summer of 1977, New York State declared a health emergency and evacuated 200 families from their houses in the area of Love Canal, a dump site for hazardous chemicals which was located near Niagara Falls, New York. Residents in the Love Canal area found chemical wastes seeping up from the ground into their basements. A wide range of health effects were alleged and feared. The federal government had to not only evacuate the residents, pay them for their homes, but also to demolish the whole neighborhood.

In 1980, the United States filed a \$ 134 million lawsuit against the company that had dumped tens of thousands of tons of chemical waste at Love Canal from the 1940s to 1950s. The complaint was primarily based on the RCRA, ${ }^{140}$ the Clean Water Act, ${ }^{141}$ and the Safe Drinking Water Act. $^{142}$ Later, the state of New York was joined as a plaintiff in the federal action with claims based on public and private nuisance and restitution. Ultimately, the case was settled and the federal government recovered $\$ 129$ million to cover its cleanup cost. New York State recovered $\$ 98$ million and the liable company further agreed to assume continued operation and maintenance of the remedial and monitoring facilities.

Before the incident of Love Canal, the U.S. Congress had already made many efforts to enact legislation addressing liability and compensation for injury to the environment from releases of hazardous substances. This event again convinced the Congress that public health and the environment were at peril because of the releases of toxins and contaminants. It became the catalyst

\footnotetext{
${ }^{138}$ Id. at 156.

${ }^{139}$ Pub. L. No. 96-510, 94 Stat. 2767 (1980) (codified as amended in scattered sections of 26 U.S.C., 33 U.S.C., and 49 U.S.C.).

${ }^{140}$ The Resource Conservation and Recovery Act, 42 U.S.C. $\$ \S 6901-92$.

${ }^{141} 33$ U.S.C. $\S \S 1251-1376$.

${ }^{142} 42$ U.S.C. $\$ 300$.
} 
for serious Congressional consideration of cleanup legislation. On December 11, 1980, Congress passed the Comprehensive Environmental Response, Compensation and Liability Act. Since then, Congress has comprehensibly amended CERCLA twice. The first time was through the Superfund Amendments and Reauthorization Act ("SARA") in 1986. ${ }^{143}$ SARA added many provisions to CERCLA and clarified much of what was unclear in the original act. In 2002, CERCLA was amended again through the implementation of the Small Business Liability Relief and Brownfields Revitalization Act ("Brownfields Amendments"). ${ }^{144}$ The purpose of this amendment still was to make the terms in CERCLAclearer.

\section{b. Basic Structure of CERCLA}

CERCLA was enacted to set up four fundamental program elements: (1) A system for information gathering and analysis; (2) Federal authority to respond to and clean up releases of hazardous substances; (3)A Hazardous Substance Response Trust Fund, which is called the "Superfund" to underwrite clean-up; and (4) A liability scheme for those responsible for releases of hazardous substances. Basically, there are four titles under CERCLA: Hazardous Substances Releases, Liability, Compensation; Hazardous Substance Response Revenue Act of 1980; Miscellaneous Provisions; and Pollution Insurance. Some of the provisions in Title One are regarded as the most significant ones in CERCLA. They are Section 107, the liability section; Section 104, which regulates the response authority; Section 106, which is about the abatement action; Section 101, the definition section; Section 105, the National Contingency Plan section; and Section 103, which gives specific requirements to reporting the releases of hazardous substances. ${ }^{145}$

\section{c. Key CERCLADefinitions}

Based on the definitions given by CERCLA, liability for environmental damages can be explained as follows:

The term "environment" means (A) the navigable waters, the waters of the contiguous zone, and the ocean waters of which the natural resources are under the exclusive management authority of the United States under Fishery Conservation and Management Act of 1976, and (B) any other surface water, ground water, drinking water supply, land surface or subsurface strata, or ambient air within the United States or under the jurisdiction of the United States. ${ }^{146}$

The term "damages" means damages for injury or loss of natural resources as set forth in Section 107 (a) or 111 (b) of this Act. ${ }^{147}$

The terms "liable" and "liability" under this title shall be construed to be the standard of liability which obtains under Section 311 of the Federal Water Pollution Control Act. ${ }^{148}$

"Facilities" is another key noun frequently appearing in statutes. In CERCLA, it is termed as:

(A) any building, structure, installation, equipment, pipe or pipeline (including any pipe into a sewer or publicly owned treatment works), well, pit, pond, lagoon, impoundment, ditch, landfill, storage container, motor vehicle, rolling stock, or aircraft, or (B) any site or area where a hazardous substance has been deposited, stored, disposed of, or placed, or otherwise come to be located; but does not include any consumer product in consumer use or any vessel. ${ }^{149}$

\footnotetext{
${ }^{143}$ Pub. L. No. 99-499, 100 Stat. 1615 (1986).

${ }^{144}$ Pub. L. No. 107-118, Stat. 2356 (2002).

${ }^{145}$ Pub. L. No. 96-510, 94 Stat. 2767 (1980) (codified as amended in scattered sections of 26 U.S.C., 33 U.S.C., and 49 U.S.C.).

${ }^{146}$ Comprehensive Environmental Response, Compensation and Liability Act, Section 101 (8).

${ }^{147}$ Comprehensive Environmental Response, Compensation and Liability Act, Section 101 (6).

${ }^{148}$ Comprehensive Environmental Response, Compensation and Liability Act, Section 101 (33).

${ }^{149}$ Comprehensive Environmental Response, Compensation and Liability Act, Section 101 (9).
} 
From this definition, we can conclude that the meaning of facilities is broad in CERCLA. Cases in which facilities are at issue perfectly correspond to this intentional expansion. For instance, in the court decision of United States v. Ward, "facility includes roadside ditches where contaminated oil was spread. ${ }^{\prime 150}$ In some situations, it even transcends normal property boundaries. The holding in United States $v$. Taylor is definitely a good proof. It said: "[...] noncontiguous facilities may be treated as a single facility where they are reasonably related on the basis of geography or the actual or potential threat to the public health or welfare or the environment."151

"Facilities" is not the only term that is given a broad definition under CERCLA; "hazardous substances" is another one. It is statutorily defined as:

(A) any substance designated pursuant to Section $311(b)(2)(A)$ of the Federal Water Pollution Control Act, (B) any element, compound, mixture, solution, or substance designated pursuant to Section 102 of this Act, (C) any hazardous waste having the characteristics identified under or listed pursuant to Section 3001 of the Solid Waste Disposal Act (but not including any waste the regulation of which under the Solid Waste Disposal Act has been suspended by Act of Congress), (D) any toxic pollutant listed under Section 307(a) of the Federal Water Pollution Control Act, (E) any hazardous air pollutant listed under Section 112 of the Clean Air Act, and $(F)$ any imminently hazardous chemical substance or mixture with respect to which the Administrator has taken action pursuant to Section 7 of the Toxic Substances Control Act.... ${ }^{152}$

From this part, we can see that CERCLA does not have its own definition of "hazardous substances."
Instead, it simply incorporates by reference the lists of toxic chemicals in other federal statutes.

Moreover, even though this provision lists some exclusiveness, like:

The term does not include petroleum, including crude oil or any fraction thereof which is not otherwise specifically listed or designated as a hazardous substance under subparagraphs (A) through ( $F$ ) of this paragraph, and the term does not include natural gas, natural gas liquids, liquefied natural gas, or synthetic gas usable for fuel (or mixtures of natural gas and such synthetic gas).

It is still the truth that the scope of "hazardous substances" is broad, and therefore, the release of almost any toxin to the environment can trigger the "Superfund."

\section{d. Liable Party under CERCLA}

Section 107 of the "Superfund" sets forth a liability allocation scheme. CERCLA imposes strict liability (often joint and several liability) for restitution of response costs incurred by the government or a private party as a result of actual or potential releases of hazardous chemicals. Four categories of responsible parties are liable: (1) owners and operators of a "facility" from which hazardous substances are threatened to be released or are actually released, (2) persons who owned or operated a facility at the time of hazardous substance disposal, (3) persons who arranged for disposal of hazardous substances, and (4) persons who transported hazardous substances and selected the disposal site. ${ }^{153}$ These persons are called potentially responsible parties ("PRP"), and as discussed later, their defense options are quite limited.

\footnotetext{
${ }^{150}$ United States v. Ward, 618 F. Supp. 884 (1985).

${ }^{151}$ United States v. Taylor, 1989 U.S. Dist. LEXIS 17477 (1989).

${ }^{152}$ Comprehensive Environmental Response, Compensation and Liability Act, Section 101 (14).

${ }^{153}$ Comprehensive Environmental Response, Compensation and Liability Act, Section 107 (a).
} 
What is worth mentioning is that "owners and operators" do not include a unit of state or local government that acquired ownership or control involuntarily through bankruptcy, tax delinquency, abandonment, or other circumstances in which the government involuntarily acquired title by virtue of its function as the sovereign power. ${ }^{154}$ The exclusion does not apply, however, to any state or local government that has caused or contributed to the release or threatened release of a hazardous substance from the facility. ${ }^{155}$ At this point, federal government is not so lucky as is a state or local government because the District of Columbia Circuit said in the case of East Bay Municipal Utility District v. United States Department of Commerce, that the federal government had waived sovereign immunity as a defense to CERCLA liability whether it is acting in a proprietary or regulatory mode. ${ }^{156}$

\section{e. Defenses}

There are not many defenses to CERCLA liability, either statutory or equitable.

The statutory defenses are available when the release or threat of release of a hazardous substance and the damages resulting therefrom were caused exclusively by (1) an act of God; (2) an act of war; (3) an act of unrelated third parties with whom a potential responsible party has no direct or indirect contractual connection, and where the potential responsible party exercises due care with respect to any hazardous chemicals. ${ }^{157}$

The defense most likely to be raised by a party is the third one, the innocent owner defenses. The 2001 Superfund Amendments expended it even where purchase of property is made with knowledge of contamination. ${ }^{158}$ The defense based on act of God has almost always failed. ${ }^{159}$ Hurricanes, heavy rains or winds, severe storms, floods, and fires caused by lightning are all foreseeable events. ${ }^{160}$ And contamination due to these incidents was preventable and not the act of God. As a consequence, unless the act of God is the only cause of the contamination and entirely unforeseeable, a defense based on this reason will probably not be successfully asserted. An "act of war" generally implies an act of combative nature. In history, there has been only one successful case based on this defense. In 1998, United States brought a lawsuit against Shell Oil Company, pursuant to $\S 107$ of the CERCLA, seeking to recover the substantial costs in its attempts to clean up a site. The damage to the site was the result of a deleterious by-product of the World War II aviation gasoline program. ${ }^{161}$ Having found both the United States and the Oil Companies liable, the United States District Court for the Central District of California needed to determine only the percentage of liability allocable to the Government and to the Oil Companies. ${ }^{162}$ After analyzing a few facts of this case, such as the government's uncontested liability; a minimum, but incomplete, estimate of the percentage of waste attributable to the avgas program; 100 percent of the non-benzol waste at the site was attributable to the avgas program; and etc. $^{163}$ The court concluded that 100 percent allocation of liability was to the United States and zero percent allocation of liability to the Oil Companies, because "the war caused the problem and like myriad others the burden must rest on the United States, which is all of us. The United States won the war and all of us paid the costs at the time. This is another such cost merely long delayed."164

\footnotetext{
${ }^{154}$ Comprehensive Environmental Response, Compensation and Liability Act, Section 101 (20) (D).

${ }^{155}$ Comprehensive Environmental Response, Compensation and Liability Act, Section 101 (20) (D).

${ }^{156}$ East Bay Municipal Utility District v. United States Department of Commerce, 330 U.S. app. D. C. 31 (1998).

${ }^{157}$ Comprehensive Environmental Response, Compensation and Liability Act, Section 107 (b).

${ }^{158}$ Steven Ferry, Environmental Law, Aspen Publishers (4th ed., 2007).

${ }^{159}$ Carole Stern Switzer and Lynn A. Bulan, Comprehensive Environmental Response, Compensation, and Liability Act (Superfund), Section of Environment Energy and Resources (2002).

${ }^{160}$ Carole Stern Switzer and Lynn A. Bulan, Comprehensive Environmental Response, Compensation, and Liability Act (Superfund), Section of Environment Energy and Resources (2002).

${ }^{161}$ United States of America v. Shell Oil Company, 13 F. Supp. 2d 1018 (U.S. Dist, 1998).

${ }^{162}$ Id.

${ }^{163}$ Id.

${ }^{164}$ Id, at 1030.
} 
Under the definition of an owner or operator provided by $\S 101$ in CERCLA, a person who "without participating in the management of a vessel or facility, holds an indicia of ownership primarily to protect his security interest in the vessel or facility" is excluded from liability. ${ }^{165}$ This is called "the secured creditor exception". However, the statute leaves an unclear question here: to what degree a person's participation in the vessel or facility reaches the level of "participating in the management?" In the following years after the enactment of CERCLA, the American Environmental Protection Agency ${ }^{166}$ issued rules clarifying this exception, but got struck down by the D.C. Circuit Court of Appeals. ${ }^{167}$ It was not until 1996, in which the Congress enacted the Asset Conservation Act, was a clear definition of "participating in the management" set up. ${ }^{168}$

Throughout CERCLA, there are another two minor defenses available to defendants. The de micromis exemption exempts generators and transporters from CERCLA liability when they can demonstrate that

(A) the total amount of the material containing hazardous substances that the person arranged for transport for disposal or treatment of, or accepted for transport for disposal or treatment, at the facility was less than 110 gallons of liquid materials or less than 200 pounds of solid materials (or such greater or lesser amounts as the Administrator may determine by regulation); and

(B) all or part of the disposal, treatment, or transport concerned occurred before April 1 , $2001^{169}$

In order to be eligible for the exemption, the materials must not have significantly contributed or be able to significantly contribute to the cost of the response action, and the claimant must not have failed to comply with any information request or have impeded any response action, or have been convicted of a criminal violation for conduct to which the exemption applies. ${ }^{170}$

The other one is the Municipal Solid Waste exemption, which excludes from liability an owner, operator, or lessee of residential property; small businesses; and small nonprofit organizations. The same eligibility limitations that are applied to the de micromis exemption also apply here. ${ }^{17}$

Almost every defendant will raise equitable and other defenses in addition to the statutory defenses, but these defenses are rarely successful. Some courts have suggested that equitable defenses such as estoppel, unclean hands, laches, and res judicata may be asserted in certain situations, but most courts have held that available defenses are limited to those enumerated in CERCLA. In addition, other defenses such as procedural omissions by EPA have always failed.

\section{f. Strict Liability and Proximate Cause}

There is no provision in CERCLA clearly saying whether the liability of potential responsible parties is based strictly on their status or whether elements of negligence should be considered. When Congress drafted CERCLA, they omitted this key issue. However, because CERCLA incorporates by reference of the Clean Water Act, whose $\$ 311$ holds violators strictly liable for marine damages, courts overwhelmingly hold potential responsible parties strictly liable in cost recovery actions under CERCLA. Therefore, CERCLA is not negligence based but strict liability based.

Proximate cause, including actual causation, connects conduct and injury together. CERCLA

\footnotetext{
${ }^{165}$ Comprehensive Environmental Response, Compensation and Liability Act, Section 101 (20) (A).

${ }^{166}$ Hereinafter EPA.

${ }^{167}$ Carole Stern Switzer and Lynn A. Bulan, Comprehensive Environmental Response, Compensation, and Liability Act (Superfund), Section of Environment Energy and Resources (2002).

${ }^{168} 42$ U.S.C. $\S 9601$ (20) (E)-(G), §9607 (n) and $§ 6991 b(h)$.

${ }^{169}$ Comprehensive Environmental Response, Compensation and Liability Act, Section 107 (o) (1) (A) and (B).

${ }^{170}$ See Comprehensive Environmental Response, Compensation and Liability Act, Section 107 (o) (2).

${ }^{171}$ See Comprehensive Environmental Response, Compensation and Liability Act, Section 107 (p).
} 
imposes proximate cause on potential responsible parties. Specific requirements of proximate cause are developed in various cases by the courts.

\section{g. Enforcement of CERCLA}

Generally speaking, all the ways to enforce CERCLA fall into two categories- mechanisms available to the government and mechanisms available to the public.

The government has the power to order a cleanup or give injunctive remedies. Section 106 of CERCLA empowers EPA with "imminent hazard" authority to take such action "as may be necessary to protect public health and welfare and the environment," after the affected state is notified. ${ }^{172}$ EPA may use either civil judicial injunctive actions or unilateral EPAadministrative orders to act.

EPA can also perform a cleanup and then bring a lawsuit to recover its costs from the potential responsible parties. Section 107 of CERCLA establishes liability for recovery of (1) costs incurred by state or federal governments that are not inconsistent with the National Contingency Plan (NCP), (2) any other necessary response costs consistent with the NCP incurred by any other person, and (3) "damages for injury to, destruction of, or loss of natural resources, including the reasonable costs" for damage assessment. ${ }^{173}$ Moreover, EPA is also allowed to recover "costs expended for investigation, monitoring, and testing; response-related planning costs; EPA and Justice Department staff costs; and litigation and attorney fees. ${ }^{174}$ Prejudgment interest also has been held to be a consistently recoverable response cost under CERCLA. However, costs related to the investigation of a potential responsible party, as opposed to investigation of the site, have been held to be not recoverable.

Bringing a lawsuit to court is not always a good idea. As a matter of fact, a large percentage of CERCLA matters are resolved through a negotiated settlement process that results in a consent decree. This settlement is also referred to as "friendly persuasion", which means after gathering information from a potential responsible party, EPA convinced that party to take voluntary clean-up action. There are many possible benefits of entering into such a negotiation: parties who choose to settle have the immunity from contribution actions brought by nonsettling parties; the remediation costs might be lower; settling parties might obtain immunity regarding any further liability. ${ }^{175}$

Besides what has been discussed above, the reporting requirements set up in CERCLA are also effective tools. Actually, the government uses the reporting requirements to determine which sites to investigate and clean up. Section 103 requires any person who is in charge of a vessel or facility, as soon as he has knowledge of any release, except for a federally permitted release, of a hazardous substance in quantities equal to or greater than those determined pursuant to CERCLA §102, he must immediately notify the National Response Center. ${ }^{176}$ Together with $\$ 104$ (e), which allows EPA to enter facilities and obtain information relating to potential responsible parties, hazardous substance releases, and liability, $\S 103$ provides EPA with a very broad information- gathering authority.

The recovery mechanism available to the public mainly refers to the citizen suit. This is considered to be the most effective way of enforcement. CERCLA encourages individuals and organizations to help promote environmental compliance. Under CERCLA, "any person" can sue on his behalf against either an alleged polluter or the government agency that is supposed to be regulating the activities of that polluter. If the plaintiff wins the case, he or she will be awarded costs and attorney's fees. On the other hand, CERCLA also sets out provisions to avoid the citizens' abuse of this power: the plaintiff

\footnotetext{
${ }^{172}$ Comprehensive Environmental Response, Compensation and Liability Act, Section 106.

${ }^{173}$ Comprehensive Environmental Response, Compensation and Liability Act, Section 107 (a) (4).

${ }^{174}$ Steven Ferry, Environmental Law, Aspen Publishers (4th ed., 2007). at 381.

${ }^{175}$ This is a statutorily created limitation of subsequent liability for settling parties. See 42 U.S.C. §9622 (f).

${ }^{176}$ Comprehensive Environmental Response, Compensation and Liability Act, Section 103 (a).
} 
must give notice to EPA as well as to the alleged polluter at least 60 days before filing the lawsuit, and provide sufficient information to the violator, letting him know what, when and where he violated. Further, if the government has already prosecuted a civil or criminal action against the defendant, a citizen suit is prohibited. The United States also preserves the right to intervene in a citizen suit.

\section{h. Statute of Limitations}

Prior to the 1986 SARA amendments, CERCLA had no specific statute of limitations provisions. However, the amendments provide limitations periods for natural resource damages, cost recovery actions, and contribution actions.

With regard to natural resource damage, the limitation period for the claims is 3 years after the latter of either (A) "[t]he date of the discovery of the loss and its connection with the release in question" or $(\mathrm{B})$ " $[\mathrm{t}] \mathrm{he}$ date on which regulations are promulgated under $\S 301$ (c)". 177

As to cost recovery actions, $\$ 113 \mathrm{~g}(2)$ has two limitation periods:

(A) for a removal action, within 3 years after completion of the removal action, except that such cost recovery action must be brought with 6 years after a determination to grant a waiver under $\$ 104(c)(1)(C)$ for continued response action; and

(B) for a remedial action, within 6 years after initiation of physical on-site construction of the remedial action, except that, if the remedial action is initiated within 3 years after the completion of the removal action, costs incurred in the removal action may be recovered in the cost recovery action brought under this subparagraph.

It also provides an extension of limitation period for removals when they are followed by a remedial action. $^{178}$
As for the contribution actions for response costs or damages, claims must be brought no more than 3 years after $(A)$ the date of judgment in any action under this Act for recovery of such costs or damages, or (B) the date of an administrative order entry of a judicially approved settlement with respect to such costs or damages. ${ }^{179}$

\section{Torts vs. Statutes}

It has always been a huge task to develop an effective central regime for regulating environmental civil liabilities. Purely case-by-case approach or enacting-statutes approach has proven to be largely ineffectual.

The rules in traditional tort serve deterrence and remediation goals poorly. In a traditional tort claim regarding environmental damages, based for example on nuisance, the plaintiff must show causation to recover more than nominal damages. Besides, he also has to prove duty of care and damages. To this point, there are advantages of bring CERCLA claims instead of common law tort claims. In a CERCLA claim, the plaintiff does not have to prove that the defendant's hazardous substances directly caused the environmental damage. Moreover, because CERCLA is a strict liability statute, the plaintiff does not have to prove that the polluter is negligent. The statute of limitations for CERCLA is longer after the defendants' actions for the plaintiff to initiate suit than that for common law claims.

However, this does not mean that CERCLA claims have no defects at all. In a CERCLA claim, plaintiff is unable to recover any damages other than response costs. This is different from a tort action, in which plaintiff may seek damages for diminution of property and emotional distress. Another defect is that any CERCLA claim has to be based on a remedial action that was performed in compliance with the National Contingency Plan, which potentially raises the cost of remediation.

\footnotetext{
${ }^{177}$ Comprehensive Environmental Response, Compensation and Liability Act, Section 113 (g) (1).

${ }^{178}$ Comprehensive Environmental Response, Compensation and Liability Act, Section 113 (g) (2).

${ }^{179}$ Comprehensive Environmental Response, Compensation and Liability Act, Section 113 (g) (3).
} 
Tort law is primarily a vehicle for reparation and cure rather than punishment while CERCLA regime focuses on remediation and prevention. They both have advantages and disadvantages. It is hard to conclude which one works better for the environmental civil liability regime. Nowadays in the U.S., although the statutes do not impose liability for personal injury, it is common for private tort actions to parallel CERCLA and state cleanup actions, and to base their claims at least in part on the same core facts as these actions. Indeed, frequently it is the discovery of offsite drinking water contamination or personal injury that prompts the initiation of federal or state cleanup action.

\subsection{Environmental Civil Liability Regime in the European Union}

The European Union (EU) was created under the Maastricht Treaty in 1992. The predecessor of the EU was the European Community (EC), an independent supranational economic organization founded by the Treaty of Rome in 1957. The EC is currently one of the three pillars of EU, and will be completely absorbed by EU in 2009 if the Treaty of Lisbon comes into force. ${ }^{180}$ During the EC era, there was no environmental policy at all. However, once the member states realized the importance of an environmental liability regime, the Commission of the EC (now EU) drafted a variety of proposals and made great progress in this field.

\subsubsection{Reasons for EU to intervene into Environmental Civil Liability}

The main objective of the EC was to promote economic expansion in order to bring about increased prosperity, employment and better housing in the post-World War II era. People were eagerly looking forward to a lasting peace in Europe with a stable social and economic condition. However, at that time, attention was focused on how to improve the economy with little appreciation for environmental policies.

The awareness that focusing solely on economic development at the expense of environmental protection could cost heavy a price generally came from Rachel Carson's book, Silent Spring. This book documented the negative effects of pesticides on the environment, especially on birds. The abuse of DDT in agriculture caused thinner egg shells and reproductive problems. As a result, the number of birds was sharply decreasing. The author was concerned that if such a situation continued, it would literally result in a "Silent Spring". The book also strictly criticized the chemical industry of spreading disinformation and public officials of accepting industry claims uncritically. ${ }^{181}$

Environmental disasters that occurred subsequently, either inside EU member-states or outside Europe, such as the 1967 Torrey Canyon and the 1976 Seveso's TCDD incidents, finally raised public consciousness of environmental issues. From these environmental pollutions, the Commission realized that in modern times, environmental problems are usually transboundary. This nature indicates that an environmental civil liability regime that works in EU-wide may be more effective than unilateral and separate regimes in different member states.

Not only the ecological need that created the political climate necessary for establishing a centralized environmental liability regime, there are also economic desires for a standard playing field for competition within internal markets. This resulted from the various restrictions on polluting activities set up by individual countries. Sometimes the variation of these restrictions raised business costs, interfered with the ability of certain member states to import and export, and disadvantaged them in the EU's internal market.

\footnotetext{
${ }^{180}$ European Community, from Wikipedia. $h$ ttp://gollum.easycp.de/gollum/gollum.php?a=core\&l=zh-cn\&wl=en\&q=

${ }^{181}$ Silent Spring, from Wikipedia, http://en.wikipedia.org/wiki/Silent_Spring.
} 


\subsubsection{EU's Developments on Civil Liability for Environmental Damage}

\section{a. The Fifth Environmental Action Program}

It was the Sandoz incident that called upon the EU commission's immediate response. There was a catastrophic fire at a chemicals factory near Basel, Switzerland in 1986, sending tons of toxic chemicals into the nearby river Rhine and turning it red. The fire broke out in a storage building used for pesticides, mercury and other highly poisonous agricultural chemicals. Firefighters spent hours extinguishing the fire. But the chemicals were also washed into the river with the water used by firefighters to tackle the fire. About 30 tons of pesticides were discharged into the river, Western Europe's most important waterway. Four countries which the river flows through - Switzerland, Germany, France and Holland-had to sound a siren to alert people to stay indoors and stay away from the river. ${ }^{182}$ To prevent such environmental disasters from occurring again and to provide remedies to the environmental damages, EU brought out a new approach that focused on the possible use of civil liability. This new measure was provided in EU's $5^{\text {th }}$ Environmental Action Program, which says:

An integrated Community approach to environmental liability will be established to make sure that, if damage to the environment does occur, it is properly remedied through restoration. Liability will be an essential tool of last resort to punish despoliation of the environment. In addition - and in line with the objective of prevention at source - it will provide a very clear economic incentive for management and control of risk, pollution and waste. ${ }^{183}$

b. Proposals on Civil Liability for Damage Caused by Waste

EU developed a sector specific response starting with the wastes. In 1989, a formal proposal on Civil
Liability for Damage caused by waste was published in the form of a draft Directive. In this proposal, a strict liability regime was established. Two years later, a more comprehensive proposal was published again to replace the 1989 Directive. ${ }^{184}$ The significance of the 1991 Waste Proposal lies in the statutory limitations. Article 10 included a 30 year statute of limitations during which time an action can be brought so as to deal with one of the features of modern environmental pollutionsthe long latency before the damage could be detected. Once environmental harm has been discovered, Article 9 (1) provided that the plaintiff must bring an action within three years of the time at which he first knew, or ought to have known, of the harm and the identity of the polluter. These provisions give better protection to the victims of environmental harm. However, the 1991 Waste Directive also has flaws: it does not include liability in respect of pollution occurring prior to the introduction of the legislation. This means that it has no restraints to historic pollutions. Moreover, its failure to define certain terms made its language sort of vague. For example, under the 1991 Waste Proposal, liability is assigned on the basis of whether or not a person had actual control of the waste at the time of pollution; however, the Proposal fails to define "actual control" in any of its provisions.

\section{c. The Council of Europe Convention on Civil Liability}

The full name for this convention is the Council of Europe Convention on Civil Liability for Damage resulting from Activities Dangerous to the Environment. Since it was agreed and opened for signature at Lugano, Switzerland, it is also called the Lugano Convention. As a matter of fact, the Lugano Convention was not initiated by the EU; instead, it was started by the Council of Europe, which was an entirely distinct body from EU. ${ }^{185}$ In June 1993, seven European countries signed the Lugano Convention.

\footnotetext{
${ }^{182}$ http://news.bbc.co.uk/onthisday/hi/dates/stories/november/1/newsid_4679000/4679789.stm

${ }^{183}$ OJ No. C 138 of 17 May 1993 (due to run until 2000).

${ }^{184}$ Council Directive on Civil Liability for Damage Caused by Waste, 1991 O.J. (C 192). Hereinafter 1991 Waste Directive.

${ }^{185}$ The Council of Europe was formed in 1948 with the purpose of promoting political and military integration in Europe.
} 
Lugano Convention has 8 chapters in total. There are General Provisions, Liability, Access to Information, Actions for Compensation and Other Claims, Relation between this Convention and Other Provisions, The Standing Committee, Amendments to the Convention, and Final Clauses. It gives detailed definition to important terms used in environmental liability regime. For example, it defines "operator" as "the person who exercises the control of a dangerous activity." ${ }^{\prime \prime 186} \mathrm{And}$ then, it further explains "person" means "any individual or partnership or any body governed by public or private law, whether corporate or not, including a State or any of its constituent subdivisions." ${ }^{117}$

Article 6 (2) and (3) provide joint and several liability with regard to a continuing occurrence or a series of consecutive occurrences that have a common origin. However, the provisions are definitely not too strict on operators since under the provisions, an operator is only liable for the specific part of damage he or she caused, providing that the operator can identify the specific part of the damage which was attributable to the period in which he was in charge of the site. ${ }^{188}$

The importance of this convention lies in that fact that EU wholly acceded to the convention instead of drafting its own. It was used by EU as a stating point for an EU initiative and it to some extent precipitated the development of the Green Paper.

\section{d. Green Paper on Remedying Environmental Damage}

In 1993, the European Commission submitted a paper to the EU discussing various options to remedy environmental damages. This paper is called Green Paper on Remedying Environmental Damage. ${ }^{189}$ The Commission believed that an effective environmental civil liability regime would advance their goals to deter future contamination and to compel responsible parties to clean up the existing environmental damages. Therefore, the Green Paper focused on the adoption of a wider system of civil liability based on "polluter should pay" principle, covering a broader range of activities.

The paper addresses many important issues including strict liability, the difficulty of establishing causation in environmental damage cases; whether normal civil remedies are adequate to compensate for environmental damage; whether adequate insurance cover could be provided for increased civil liability, etc. There are three main sections in the Green Paper. The first section discusses the basic questions in the environmental civil liability regime, such as liability standard, damages, causation and remedies. The second part introduces the joint compensation system, its advantages and problems. The third section points out the possible directions for community action. ${ }^{190}$ One major progress the Green Paper makes compared to the 1991 Waste Directive is that it considers means by which central clean up funds could be established for use in circumstances where civil liability cannot be established.

One of the features of the Green Paper is that strict liability and fault-based liability co-exist in the Paper. This is because the Commission has realized that there are limitations to strict civil liability. They noticed that although applying strict liability could help ease plaintiffs' burden of proof by removing the need to prove fault, overuse of strict liability can only lead to the frustration of industry. As a consequence, the Commission has suggested a system of joint compensation- a financial structure based on charges or contributions. This is similar to insurance in that the funds collected are designated

\footnotetext{
${ }^{186}$ The Council of Europe Convention on Civil Liability Resulting from Activities Dangerous to the Environment, March 1993. (Lugano Convention), Article 2 (5).

${ }^{187}$ The Council of Europe Convention on Civil Liability Resulting from Activities Dangerous to the Environment, March 1993 . (Lugano Convention), Article 2 (6).

${ }^{188}$ The Council of Europe Convention on Civil Liability Resulting from Activities Dangerous to the Environment, March 1993 . (Lugano Convention), Article 6 (2) (3).

${ }^{189}$ Green Paper on Remedying Environmental Damage, COM (93) 47 final, Mar. 1993. Hereinafter, the Green Paper.

${ }^{190}$ Green Paper on Remedying Environmental Damage, COM (93) 47 final, Mar. 1993.
} 
for a specific purpose, such as cleaning up or restoring the environment. The principle of liability for particular acts is expanded into a principle of shared responsibility for the impact of multiple acts. ${ }^{191}$ Such joint compensation system is a concrete application of the "polluter pays" principle since it is sustained by contributions form the economic sectors most closely linked to the type of damage that needs to be restored. This is quite similar to CERCLA in the U.S., which make up for the deficiencies of a strict liability scheme.

EU clearly expressed its intention to establish an effective system of civil liability for environmental damages in the Green Paper; however, it left the most important question unanswered: Who is supposed to be held liable? The operator? Or perhaps financial institutions such as the insurance companies?

\section{e. White Paper on Environmental Liability}

In recent years, EU has experienced a series of environmental disaster caused by human beings. For example, on December 12, 1999, the Erika broke in two off the coast of Brittany, France, carrying approximately 30,000 tonnes of fuel oil, 19,800 tonnes of which were spilled into the sea. It took a long time to pump the remaining oil to the surface and clean up the polluted coastline. This incident resulted in the miserable death of tens of thousands of seabirds and other animals. ${ }^{192}$ Unfortunately, this is also not the first oil-leak incident resulting in serious environmental damage. A few months before the Erika incident, in late April 1998, a dam storing mining waste at the Los Frailes lead and zinc mine burst and released a black river of toxic sludge that devastated plant and wildlife, narrowly missing the Donana nature reserve in south Spain. ${ }^{193}$ EU's response to these events was White Paper on Environmental Liability, which is frequently referred to as EU's "superfund".
The White Paper was eventually published in February, 2000. It re-stresses many issues raised in the Green Paper, such as imposing strict liability and easing the burden of proof. There are 8 parts in the White Paper. The first two parts introduce some background information and explain what environmental liability is. Part 3 is about the significance of EU's environmental liability regime. Part 4 talks about possible features of EU's environmental liability regime. Part 5 makes some comparison and contrast of various options for action. Part 6 discusses the questions brought by subsidiarity and proportionality. Part 7 explores the overall economic impact of environmental liability at the EU level. Part 8 concludes the next action to set up a common environmental civil liability regime in EU. ${ }^{194}$

The main characteristics of EU's environmental civil liability regime set by the White Paper are as follows: (1) no retroactivity, which means the Paper only applies to future damages; (2) the scope of the regime not only covers environmental damage, which includes damage to biodiversity and damage in the form of contamination of sites, but also covers traditional damage, which consists of personal injury and property damage; (3) strict liability applies to damages caused by inherently dangerous activities while fault-based liability applies to biodiversity damages caused by nondangerous activities; (4) allows commonly accepted defenses, such as force majeure, contribution to the damage or consent by the plaintiff, and intervention by a third party, etc, which aims at balance the interests of plaintiff and defendant; (5) the liable party is the operator who exercises control of an activity by which the damage is caused; (6) ensures effective decontamination and restoration of the environment; (7) "two-tier approach" to access to justice; (8) compatible with international conventions; (9) provides financial insurance to reduce the risks to which companies are exposed. ${ }^{195}$

\footnotetext{
${ }^{191}$ Green Paper on Remedying Environmental Damage, COM (93) 47 final, Mar. 1993. at 20.

${ }^{192}$ http://www.iopcfund.org/erika.htm

${ }^{193}$ http://www.planetark.org/dailynewsstory.cfm/newsid/15665/newsDate/26-Apr-2002/story.htm

${ }^{194}$ White Paper on Environmental Liability, COM (00) 66 final, Sept. 2000. at 3.

${ }^{195}$ See White Paper on Environmental Liability, COM (00) 66 final, Sept. 2000.
} 
It is worth mentioning that even though this White Paper seems to have a number of effective features, it still received a great deal of criticism from member states which already had their own legislation designed to remedy environmental damages. Member states argued that they could better address environmental issues according to their own domestic situations. The EU argued that to have a common environmental civil liability regime would avoid distortions with EU's single market, since individual liability systems were inconsistent. Moreover, crucial principles such as the polluter pays principle were not being properly applied in some of the member states. Finally, since national legislation cannot effectively cover transboundary environmental pollution within the EU, a common regime was necessary to deal with such incidents.

\section{f. Directive on Environmental Liability}

In 2004, EU adopted another Directive relating to environmental protection, that is, Directive on Environmental Liability with Regard to the Prevention and Remedying of Environmental Damage. ${ }^{196}$ The purpose of this Directive is to establish a framework of environmental liability based on the "polluter-pays" principle, to prevent and remedy environmental damage ${ }^{197}$ There are 23 articles in total and two annexes.

"Damage" is defined in this Directive as "a measureable adverse change in a natural resource or measurable impairment of a natural resource service which may occur directly or indirectly." ${ }^{\prime 198}$ Environmental damages cover three categories: natural damage, water damage and land damage. It requires a "significant adverse effect or risk." However, how "significant" it should be is not defined.
Article 7 provides a chance for operators to identify the potential remedial measures and submit them to the competent government authority for approval. The authority has the power to decide and choose which remedial measures shall be implemented. On the contrary, Directive 2004 does not address situations in which the operators and the government authority disagree about the necessary remedial measures to be taken. Maybe in that case, the authority could perform the measures deemed necessary and recover the costs incurred later. ${ }^{199}$

Directive 2004 does not apply to environmental damages or imminent threats of such damages arising from oil spill incidents, carriage of hazardous and toxic substances by sea, by road, rail or inland ships. This is because civil liabilities for such damages have already been covered by a number of international conventions. It also does not apply to nuclear risks, as Article 4 (5) says that damage caused by pollution of a diffuse character is only covered "where it is possible to establish causation between the damage and the activities of individual operators." ${ }^{200}$ Finally, the Directive does not apply to national defense, international security and civil protection activities. ${ }^{201}$ The statutory limitation is 30 years, since Article 17 says that when more than 30 years have passed since the emission, event or incident that caused the damage occurred, Directive 2004 will not apply.

\subsubsection{Features of EU's Environmental Civil Liability}

\section{a. Liability Standard}

The English case Rylands v. Fletcher pronounces a standard of strict liability- that is, liability imposed even without a finding of negligence on the part of the defendant. Even though this standard of liability was born in one of the member states of the EU, the

\footnotetext{
${ }^{196}$ Hereinafter Directive 2004.

${ }^{197}$ Directive on Environmental Liability with Regard to the Prevention and Remedying of Environmental Damage, 2004/35/EC. Article 1.

${ }^{198}$ Directive on Environmental Liability with Regard to the Prevention and Remedying of Environmental Damage, 2004/35/EC. Article 2 (2).

${ }^{199}$ Directive on Environmental Liability with Regard to the Prevention and Remedying of Environmental Damage, 2004/35/EC. Article 6 and 8.

${ }^{200}$ Directive on Environmental Liability with Regard to the Prevention and Remedying of Environmental Damage, 2004/35/EC. Article 4 (5).

${ }^{201}$ Directive on Environmental Liability with Regard to the Prevention and Remedying of Environmental Damage, 2004/35/EC. Article 4 (6).
} 
idea of applying it to environmental damages was definitely not so widely and quickly accepted by the EU as it was by the U.S. Critics of strict liability said that in certain situations, fault-based liability may provide a superior incentive for complying with regulatory standards than strict liability and relied on an empirical study which showed that the introduction of strict liability led to an increase in automobile accidents. ${ }^{202}$ However, the use of faultbased liability in environmental tort became a big problem, since fault-based liability does not adequately prevent pollution from occurring. Then the Commission began to accept strict liability theory in environmental damages.

The 1991 draft proposal- Waste Directive provided that "[t]he producer of waste shall be liable under civil law for the damage and impairment of the environment caused by the waste, irrespective of fault on his part.".03 The producer is defined as anybody "who in the course of a commercial or industrial activity, produces waste and/or anyone who carries out pre-processing, mixing or other operations resulting in a change in the nature or composition of this waste. ${ }^{.204}$ Additionally, importers of waste are also considered to be producers as are those who had actual control of the waste at the time the pollution occurred, unless they can identify the originator of the waste and those responsible for any installation, establishment or undertaking at which the waste was held at the time the pollution occurred. ${ }^{205}$ In the Waste Directive, the only available defense to strict liability is force majeure. And as mentioned before, liabilities for historic pollution are also excluded.

The Lugano Convention requires signatories to introduce strict liability with regard to "dangerous activities". It says that " $[t]$ he operator in respect of a dangerous activity... shall be liable for the damage caused by the activity as a result of the incidents at the time or during the period when he was exercising control of that activity." Defenses provided by the Convention are set out in Article 8: the operator shall not be held liable in respect of incidents resulting from acts of war, hostilities, civil war, insurrection or natural phenomena of "an exceptional, inevitable and irresistible character". Moreover, there are other exemptions such as liability with regard to deliberate damage caused by a third party when the operator has taken sufficient measures to prevent such events; compliance with a specific order or compulsory measure of a public authority; pollution which is at tolerable levels according to local circumstance; activities undertaken lawfully in the interests of the person who suffered the damage provided that the action was reasonable. ${ }^{206}$

Either Green Paper or White Paper expresses the need to apply strict liability standard to environmental tort. The Green Paper argued from the standpoint of the polluter pays principle. It said that strict liability accorded more closely with the polluter pays principle in that it requires the operator to internalize a greater proportion of the pollution costs. It also noted the difficulties for the plaintiff to establish fault where the operator complied with regulatory standards. The White Paper supported this opinion and also stated that activities which are not dangerous per se, but have the potential, in certain circumstances, to cause health damage or significant environmental damage should also be subject to strict liability.

In conclusion, it seems that strict liability standard is becoming popular in the EU's environmental civil liability regime. And the EU certainly does not apply the standard blindly. It also provides defenses and limitations to the strict liability rule in order to prevent it from turning absolute liability.

\section{b. Burden of Proof}

The difficulties encountered by plaintiffs in establishing causation are discussed in Section II in

\footnotetext{
${ }^{202}$ Devlin, R.A., Some Welfare Implications of No-Fault Automobile Insurance Regimes, 10 International Review of Law and Economics 193.

${ }^{203}$ Council Directive on Civil Liability for Damage Caused by Waste, 1991 O.J. (C 192), article 3.

${ }^{204}$ Council Directive on Civil Liability for Damage Caused by Waste, 1991 O.J. (C 192), article 2 (1)(a).

${ }^{205}$ Council Directive on Civil Liability for Damage Caused by Waste, 1991 O.J. (C 192), article 2 (1)(a)(C)

${ }^{206}$ The Council of Europe Convention on Civil Liability Resulting from Activities Dangerous to the Environment, March 1993.
} 
this paper. Regarding this problem, EU is trying to balance the interests of plaintiffs and defendants, in order to reduce the burden of proof on causation for victims in its legislations without holding operators liable for damages to which they did not contribute.

\section{In 1991 Waste Directive, Article 4 (1) (c) says that}

The burden of proof on the plaintiff, when affirming the causal link between the wastes on the one hand and the damage or impairment of the environment suffered or likely to be suffered on the other hand; the burden of proof shall be no higher than the standard burden of proof in civillaw. ${ }^{207}$

\section{Article 10 of Lugano Convention provides that}

When considering evidence of the causal link between the incident and the damage or, in the context of a dangerous activity as defined in Article 2, paragraph 1, subparagraph $d$, between the activity and the damage, the court shall take due account of the increased danger of causing such damage inherent in the dangerous activity. ${ }^{208}$

Obviously this provision requires courts to use a lesser standard of proof if the operation in question is particularly suited to causing the damage in question. However, the words are rather vague since they do not clearly define how much is the "due amount".

Both the Green Paper and the White Paper clearly expressed the concern for the difficulties in establishing a causation connection in modern environmental tort, and reiterated the need to ease the burden of proof regarding causation. However, neither of them expands upon how this would be achieved. Maybe in light of these considerations and some successful examples of its member states, the EU will come up with some harmonized causation tests within environmental civil liability regime sooner or later.

\section{c. Standing}

In tort theory, liability is contingent on personal loss. Thus, technically speaking, claims based on environmental damages should be brought by individuals who experienced personal injury or whose property rights were interfered in the pollution. Yet under some circumstances, individuals may choose not to sue. Further, even if they decide to bring a lawsuit, the information gap between the claimants and the polluters often prevents plaintiffs from pursuing their rights. In this case, it is necessary to recognize the existence of an equitable public interest in environmental protection. That is, reducing the limitations to standing.

In a number of EU member states, legislators have already begun to dilute the differences between the public interests and the individual interests in environmental matters in order to provide standing to non-governmental organizations. To better protect the public interest in the environment, the EU requires its member states in Waste Directive to guarantee the standing of interest groups. It notes that common interest groups or associations, which have as their object the protection of nature and the environment, shall have the right to seek any remedy or to join in legal proceedings. ${ }^{209}$

In Article 18 of the Lugano Convention, it states that the Convention affords standing to "any association or foundation which according to its statutes aims at the protection of the environment" if it meet the precondition of compliance with any further conditions of internal law. ${ }^{210}$ This provision enables an organization to take legal actions to prohibit dangerous and unlawful activities that pose

\footnotetext{
${ }^{207}$ Council Directive on Civil Liability for Damage Caused by Waste, 1991 O.J. (C 192), article 4 (1)(c).

${ }^{208}$ The Council of Europe Convention on Civil Liability Resulting from Activities Dangerous to the Environment, March 1993. Convention), article 10.

${ }^{209}$ Council Directive on Civil Liability for Damage Caused by Waste, 1991 O.J. (C 192), article 4 (3).

${ }^{210}$ The Council of Europe Convention on Civil Liability Resulting from Activities Dangerous to the Environment, March 1993 . (Lugano Convention), article 18.
} 
a threat to the environment, and meanwhile, leaves domestic jurisdictions freedom to decide when such a request should be accepted.

However, environmental pressure groups are not granted the right to sue through all the EU's conventions. In Green Paper, the notion that interest group should be afforded standing is entirely rejected. It notes that "where damage occurs to property that is not owned, no injured party with the right to bring a legal action can be identified. With no legal or natural person to sue on behalf of the environment, the costs of restoring environmental damage cannot be recovered via civil liability." ${ }^{211}$

The White Paper somewhat changed the extreme rule set up in the Green Paper., as it appears to provide public interest groups with the right to sue while also restricting their power. It concedes that "there are limits to the availability of public resources for this, and there is a growing acknowledgement that the public at large should feel responsible for the environment and should under circumstances be able to act on it behalf." ${ }^{212}$ It sets up a two tier approach: first, member states should be under a duty to ensure restoration of biodiversity damage and decontamination by using the compensation or damages paid by the polluters; second, if the government does not act at all or responds in an inadequate manner, public interest groups would act on a subsidiary basis. ${ }^{213}$ This approach is significant in that it provides public interest groups certain, not excessive power, while at the same time preventing government authorities from shirking their responsibilities.

Articles 11 and 12 of Directive 2004 provide to natural or legal persons who are "affected or likely to be affected by environmental damage" a right to request the competent authority to take action in order to prevent or remedy environmental damage.
A non-governmental environmental protection organization shall be deemed to have a sufficient interest or to have rights which are capable of being impaired. These persons shall have access to a court to ask for reviews of the procedural and substantial legality of the decisions, acts or failures of the government authority. ${ }^{214}$

\section{d. Remedies}

For some time, some have argued that an effective environmental civil liability regime should not only reflect private loss but also environmental impairment. The EU has been working as regards environmental impairment for a while and really made some progress.

The 1991 Waste Proposal allows for the recovery of damages caused by waste in respect of death, physical injury, damage to property and environmental impairment. It defines "environmental impairment" as: "any significant physical, chemical or biological deterioration of the environment insofar as this is not considered to be damage within the meaning of sub-paragraph (c) (11). ${ }^{215}$ As to significant deterioration, it refers to the damages that are tangible and capable of being rectified.

In common with the Waste Proposal, Lugano Convention also includes recovery for death, personal and property damages and injury to the environment. It also gives a definition to "environmental impairment":

loss or damage by impairment of the environment in so far as this is not considered to be damage within the meanings of subparagraphs $a$ or $b$ above provided that compensation for impairment of the environment, other than for loss of profit from such impairment, shall be limited to the costs of

\footnotetext{
${ }^{211}$ Green Paper on Remedying Environmental Damage, COM (93) 47 final, Mar. 1993. at 11.

${ }^{212}$ White Paper on Environmental Liability, COM (00) 66 final, Sept. 2000. at 21.

${ }^{213}$ White Paper on Environmental Liability, COM (00) 66 final, Sept. 2000. at 22.

${ }^{214}$ Directive on Environmental Liability with Regard to the Prevention and Remedying of Environmental Damage, 2004/35/EC. Article 11 and 12.

${ }^{215}$ Council Directive on Civil Liability for Damage Caused by Waste, 1991 O.J. (C 192).
} 
measures of reinstatement actually undertaken or to be undertaken; the costs of preventive measures and any loss or damage caused by preventive measures. $^{216}$

Compared to the definition provided by the Waste Proposal, this definition is somewhat vague and complex.

The Green Paper recognizes the difficulty to place a monetary value on certain environmental damages, and thus, it focuses on the costs of tangible environmental restoration. It also realizes that it is hard to identify at which point the environment becomes sufficiently degraded by pollution to warrant remedies. ${ }^{217}$ In the White Paper, it points out that restoration of the environment to its exact former status may not be technically realistic or financially viable, whereas it does not come up with any functional solutions. ${ }^{218}$

From the discussion above, we can conclude that even though the EU focused its attention only on economic revival at the beginning, after it realized how important environmental protection could be, it is gradually making progress in establishing an effective environmental civil liability regime and it has reached some significant achievements. Certainly the EU's environmental civil liability regime is not a perfect one; however, by learning from successful examples and unsuccessful lessons of its member states or other countries, such as the U.S, its environmental civil liability regime will become more effective.

\section{CONCLUSIONES}

Civil liability is the most significant liability in the environmental liability regime since it is the regime most frequently used in environmental pollution cases. Environmental tort has developed new features in addition to those found in traditional tort. For instance, tortious actions no longer directly act on injured party; instead, the environment can be a medium that results in physical or mental injury to victims. Also, since the source of a contaminant is sometimes difficult to locate with current technology, environmental polluters can be difficult to identify. Further, it is also not easy to pinpoint the victims under some circumstances. Moreover, in an environmental tort case, the status of plaintiff and defendant is not equal because of the unbalanced economic status and the information available to the respective parties; many environmental damages have significant latency periods, and this can cause problems identifying the injury. Regarding the scope of environmental harm, once the tortious action has caused harm to the environment, the result tends to be more severe than those in traditional tort. Finally, in some situations, the actions that caused physical injury or property damage to other people might not necessarily violate the law.

There are three elements that constitute environmental civil liability: conduct, harm and causation. Since the new features of environmental tort place plaintiffs in a relatively weak position, most countries reduce the burden of proof on plaintiffs, apply strict liability standard in cases relating environmental damages, extend statutory limitations, and remove some standing requirements. On the other hand, in order not to be too strict on defendants and not to restrict too much on the growth of economy, defendants are provided with some defenses and exemptions against environmental civil liability.

The United States and the European Union worked a lot on their environmental civil liability systems. United States regulates it in two ways: by common law and by statutes. The most important statute with regards to environmental civil liability is CERCLA, the "Superfund". Both common law and statutes have its own advantages and disadvantages; together, they work well to help the United States to set up a well-functioning environmental civil liability regime. The European Union changed its approach

\footnotetext{
${ }^{216}$ The Council of Europe Convention on Civil Liability Resulting from Activities Dangerous to the Environment, March 1993. (Lugano Convention), article 7.

${ }^{217}$ See Green Paper on Remedying Environmental Damage, COM (93) 47 final, Mar. 1993.

${ }^{218}$ See White Paper on Environmental Liability, $\operatorname{COM}(00) 66$ final, Sept. 2000.
} 
to the relationship between the economy and the environment after it realized that environmental problems could totally destroy the fruits of economic development. It drafted and proposed a number of directives and papers to regulate Member States' environmental civil liability regimes.

Furthermore, legislation regarding environmental civil liability in European Union and the United States share some common features. Both apply the strict liability standard, reduce the burden of proof on the plaintiffs, expand standing to environmental interest groups, and meanwhile also provide basic defenses to the defendants. Most of European Union's environmental legislations were passed after the U.S. "Superfund." This means that European Union has opportunities to learn from the U.S example and also to avoid U.S failures in drafting and implementing legislation on environmental civil liability, if any. I hope this study on modern environmental civil liability and overview of the environmental civil liability regimes in the U.S and the EU will help China's legislators learn from their successful examples if they are applicable to our national conditions, while also trying to avoid any unsuccessful policy experiences.

\section{BIBLIOGRAPHY}

\section{Primary Sources:}

1. Comprehensive Environmental Response, Compensation, and Liability Act of 1980, Pub. L. No. 96510 , 94 Stat. 2767.

2. International Environmental Law, Primary Materials, (Michael R. Molitor ed., KLUWER Law and Taxation Publishers 1991).

3. 42 U.S.C. $\$ \S 9601-9657(2003)$.

4. 42 U.S.C.A. $\$ \$ 701-(76920)$.

\section{Secondary Sources:}

1. Abraham, Kenneth S., (2002). The Relation between Civil Liability and Environmental Regulation: An Analytical Overview, 41 Washburn L.J. 379.

2. Amended Proposal for Council Directive on Civil Liability for Damage Caused by Waste, 34 O.J. Eur.Comm. 6 (1991).

3 . Black Christine, (1995). Saving the Green: Who Should Pay for Environmental Cleanup Costs?, 20 J. Corp. L. 671.

4. Brealey, Mark, (1993). Environmental Liabilities and Regulation in Europe, The Hague: International Business Pub. Ltd.

5. Cai Shouqiu, Huanjing Ziyuanfa Jiaocheng, (2002). Wuhan University publisher.

6. Chen Yingxu, Huanjingxue, (2001). China Environment and Science publisher.

7. Cummings, Susan S., (1994). Environmental Protection and Privatization: the Allocation of Environmental Responsibility and Liability in Sale Transactions of State-owned Companies in Poland, 17 Hastings Int'I \& Comp. L. Rev. 551.

8 . Environmental Law and Enforcement in the Asia-Pacific Rim, (Terri Mottershead ed., Sweet \& Maxwell Asia 2002).

9 . Gaines, (1989). International Principles for Transnational Environmental Liability: Can developments in Municipal Law Help Break the Impasse?, 30 Harv. Int'I L.J.

10 Gentry, (1990). Environmental Regulation in Europe: Hazardous Waste and Contaminated Sites, 10 Nw. J. Int'I L. \& Bus. 397.

11. Green Paper on Remedying Environmental Damage, (1993). Commission of the European Communities, Brussels, May 14. 
12. Hylton, Keith N., (2002). When Should We Prefer Tort Law to Environmental Regulation?, 41 Washburn L.J. 515.

13. Implementing International Environmental Law in Germany and China, (2001). International Environmental Law and Policy Series, Volume 59, Tao, Zhenghua et al. eds., Kluwer Law International.

14 Le Goff, Pierrick B., (1997). The French Approach to Corporate Liability for Damage to the Environment, 12 Tul. Euro. Civ. LF 39.

15. Lv Zhongmei, Huanjingfa Jiaocheng, (2001). China Legal System publisher.

16. McCann, Michael R., (1992). CERCLA \& the European Community's Civil Liability Proposal: A Comparison of American and European Law Pertaining to Liability for Environmental Harm Caused by Hazardous Wastes, 2U. Balt. J. Envtl. L. 146.

17. Mushkat, Roda, (2004). International Environmental Law and Asian Values: Legal Norms and Cultural Influences, UBC Press.

18. Nanda, Ved P., and Pring, George, (2003). International Environmental Law \& Policy for the 21st Century, Transnational Publishers, Inc., Ardsley, New York.

19. Public Environmental Law in the European Union and the United States, A Comparative Analysis, (Seerden, Rene J.G.H., etal. eds., Kluwer Law International 2002).

20 Sadeleer, Nicolas, (2002). Environmental Principles from Political slogans to Legal Rules, Oxford Press

21 Smith \& Hunter, (1991). The Revised European Community Civil Liability for Damage from Waste Proposal, 21 Envtl. L. Rep. 10.

22. White Paper on Environmental Liability, Commission of the European Communities, Brussels, Febrero $9,2000$. 